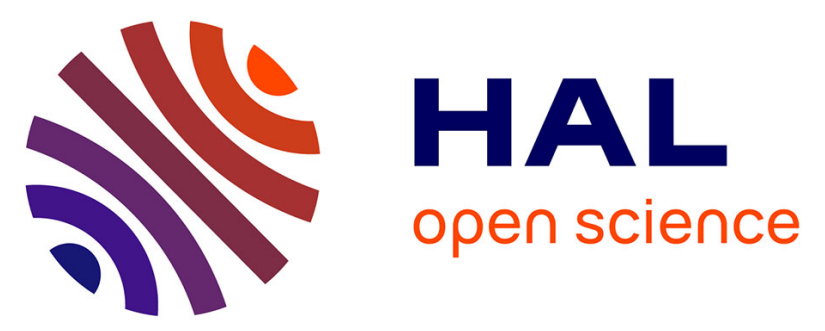

\title{
Understanding Late Pleistocene human land preference using ecological niche models in an Australasian test case
}

\author{
Alexandra J Zachwieja, Anne-Marie Bacon, Thi Mai Huong Nguyen, Anh \\ Tuan Nguyen, Kira Westaway, Philippe Duringer, Jean-Luc Ponche, Elise \\ Patole-Edoumba, Phonephanh Sichanthongtip, Thongsa Sayavongkhamdy, et
} al.

\section{To cite this version:}

Alexandra J Zachwieja, Anne-Marie Bacon, Thi Mai Huong Nguyen, Anh Tuan Nguyen, Kira Westaway, et al.. Understanding Late Pleistocene human land preference using ecological niche models in an Australasian test case. Quaternary International, 2020, 563, pp.13-28. 10.1016/j.quaint.2020.09.026 . hal-03429041

\section{HAL Id: hal-03429041 https://hal.science/hal-03429041}

Submitted on 15 Nov 2021

HAL is a multi-disciplinary open access archive for the deposit and dissemination of scientific research documents, whether they are published or not. The documents may come from teaching and research institutions in France or abroad, or from public or private research centers.
L'archive ouverte pluridisciplinaire HAL, est destinée au dépôt et à la diffusion de documents scientifiques de niveau recherche, publiés ou non, émanant des établissements d'enseignement et de recherche français ou étrangers, des laboratoires publics ou privés. 


\title{
Understanding Late Pleistocene human land preference using ecological niche models in an Australasian test case
}

\author{
Alexandra J. Zachwieja a,b, ${ }^{\text {, }}$ Anne-Marie Bacon ${ }^{c}$, Thi Mai Huong Nguyen ${ }^{d}$, Anh Tuan Nguyen ${ }^{\text {, }}$ \\ Kira Westaway e, Philippe Duringer ${ }^{f}$, Jean-Luc Ponche ${ }^{f}$, Elise Patole-Edoumbag, \\ Phonephanh Sichanthongtip ${ }^{h}$, Thongsa Sayavongkhamdy ${ }^{\text {h }}$, Tyler E. Dunn ${ }^{\text {b,i }}$, Fabrice Demeter ${ }^{j, k}$, Laura L. Shackelford ${ }^{b}$
}

\footnotetext{
a Department of Biomedical Sciences, University of Minnesota Duluth School of Medicine, USA Department of Anthropology, University of Illinois at Urbana-Champaign, USA 'Centre National de la recherche scientifique FRE2029 Babel, Universit'e Paris Descartes, France d Institute of Archaeology, Vietnamese Academy of Social Sciences, Viet Nam e Department of Environmental Sciences, Macquarie University, Australia ${ }^{\dagger}$ Ecole de Observatoire des Sciences de la Terre, Universit' e de Strasbourg, France ' Mus'eum d'Histoire Naturelle de la Rochelle, France

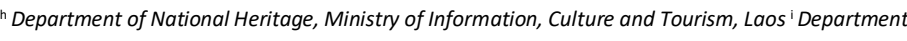
of Medical Education, Creighton University School of Medicine, USA ' Lundbeck Foundation Geogenetics Centre, Copenhaguen, Denmark ${ }^{k}$ UMR7206 Eco-anthropologie, Mus'eum National d'Histoire Naturelle, Mus'ee de l'Homme, France
}

\section{Keywords:}

Human land preference

Ecological niche modeling

Southeast Asia

Competition

Late pleistocene
A B STR A C T

Ecological niche models (ENM) of species distributions and dispersal patterns are well established in the biological sciences. Their use in paleoanthropological reconstructions of hominin niches is relatively recent, successfully focusing on out of Africa dispersals and human land preference in Europe and Central Asia. These studies have suggested that some of the most important variables for predicting human site use in these regions are moderate annual temperature and rainfall. Here, we used ENM to combine these long-used abiotic predictors of human land preference with landform data (slope) and one potentially important biotic variable (human- carnivore competition quantified using a competition index) in an Australasian test case. We constructed ENMs in the program Maxent to investigate the impact of these abiotic and biotic variables on human land preference patterns in Late Pleistocene Australasia. Though calculated competition across test sites was high, models including this biotic data produced ill-fitting localized models ( $A U C=0.695$ ) that relied on mean annual temperature. Large-scale models including solely temperature and rainfall fit well (AUC $=0.84$ ) but are poor predictors of land preference compared to models including slope in this mountainous region ( $A U C=0.924$ ) showcasing a discrepancy between accuracy and precision in abiotic models. While the biotic data included in these models was considered unimportant to predictions of human land preference, the inclusion of additional landform data in temperate ENMs should be pursued given the importance of slope as a predictor in large-scale models.

\section{Introduction}

Ecological niche models (ENM) are a class of methods that have been widely used in ecological and biological analyses to predict approximations of a species' niche based on known species distribution data (Sillero, 2011). ENMs predict these "suitable niches" for a given test species based on the input of environmental predictor data across the area of interest correlated with known species distributions (extant or fossil) to create statistically predicted species distribution data. These models often employ abiotic variables (nonliving components of an organism's environment that affect survival, niche preference, and movement) and, to a lesser extent, biotic variables (living components of an organism's environment that similarly affect the organism) (Guisan and Thuiller, 2005; Gavin et al., 2014; Maguire et al., 2015). 
ENMs can be applied to predict the present, future (forecasting), and past (hindcasting) distribution of any species, with applications for conservation, climate change mediation, and evolutionary biology. With regard to the hindcasting of data, the use of ENM in paleontological studies to provide niche predictions is widespread in plants and animals and has been used to identify longstanding Pleistocene refugia that can then be validated against known fossil assemblages (Martínez-Meyer and Peterson, 2006; Bigg et al., 2008; Varela et al., 2010, 2011; Svenning et al., 2011; Gavin et al., 2014; Maguire et

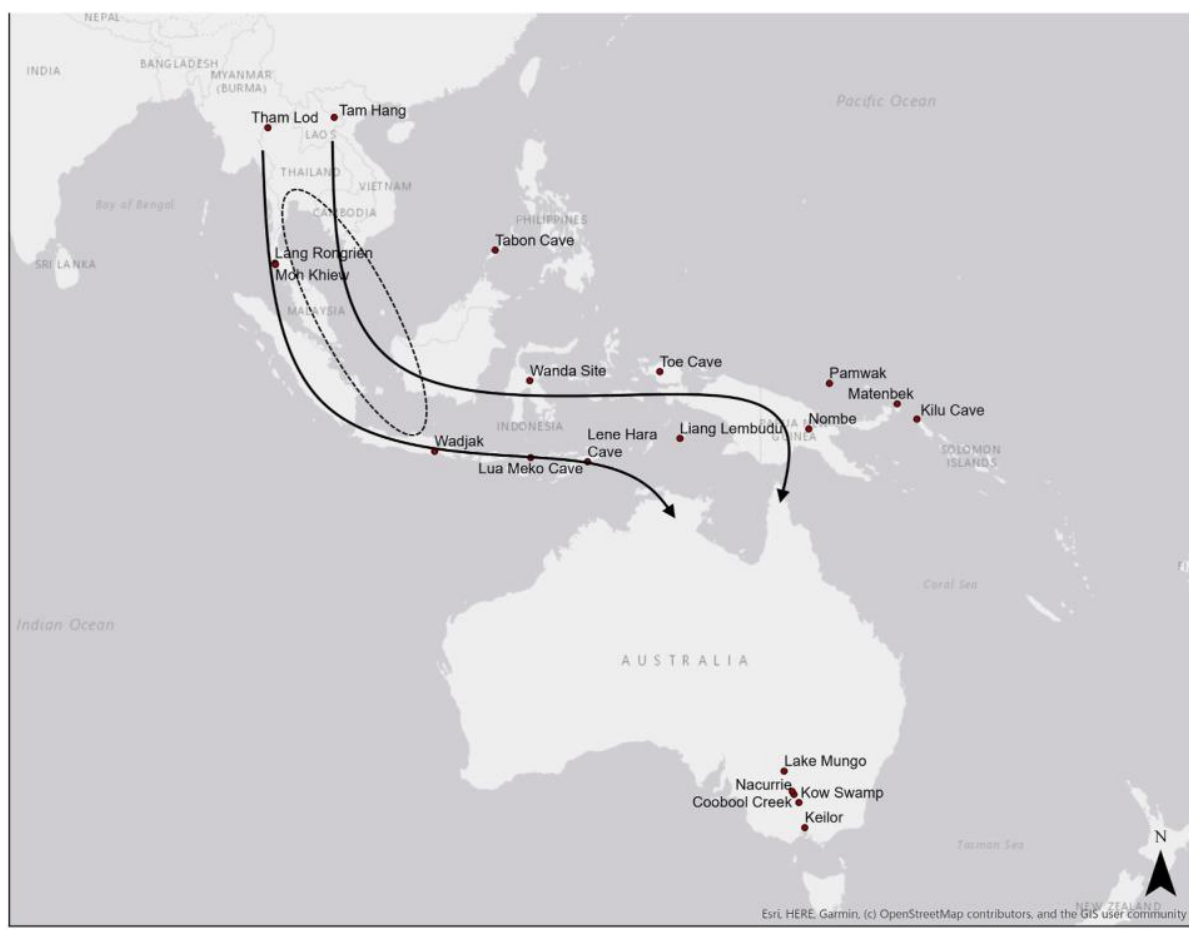

al., 2015).

Traditionally, human or hominin specific paleo-ecosystem modeling has presented a gap in the literature. Recently, however, ENM has been applied to the study of human evolution to create predictions of hominin land preference, site use during periods of intense climate fluctuations, and dispersal pathways in relatively extreme climates. Studies on Neandertals in Europe (Bible, 2016; Bible and Peterson, 2018) and early modern humans in the foothills of the Altai mountains (Beeton et al., 2014; Glantz et al., 2018) have provided evidence that some of the most important variables for predicting hominin niches and dispersal patterns are variations in temperature and precipitation (often the primary abiotic variables used in ENM analyses).

Australasia became a likely place for hominin dispersal in the Late Pleistocene, likely because of drastic climatic and geographical changes that made this space largely temperate and resource dense. This region presents a particularly interesting opportunity for an ENM test case for two reasons: 1) there are longstanding debates about human dispersal pathways in this region and 2) unlike other uses of ENM in studies of human evolution, Late Pleistocene Australasia maintained a temperate environment, which may affect the types of variables important in paleo-ecosystem modeling. There are two key routes that have been discussed in ongoing analyses of human dispersal pathways to Australia - a "northern", largely savannah, inland route (through Borneo, Talaud Islands and Papua New Guinea) and a "southern", tropical forest/coastal route (Sumatra, Java, Flores, and through East Timor to the north Australian coast) (Fig. 1). Despite being geographically close, the northern and southern routes in question have quite different environmental contexts - with savannah and open forest ecosystems in the north, and more densely forested temperate to tropical rainforest ecosystems as well as coastal resources in the south which affected trophic interactions between species. These data suggest that this region is a prime candidate for a test case employing ENM methods to predict human land preference in the context of environmental data. However, the long-standing temperate environment of Australasia fundamentally differs from other regions where ENM has been applied in human evolutionary studies. Without extreme variation in temperature and precipitation, the most important variables in predicting human land preference and dispersal patterns in these models, (Beeton et al., 2014; Bible, 2016; Bible and Peterson, 2018; Glantz et al., 2018) it is unclear how individual abiotic variables (e.g., temperature, rainfall, landform data, aridity, etc.) or biotic factors (competition, distribution of vegetation and prey species, etc.) may have influenced human dispersal or land preference in temperate Australasia. Employing these unique environmental data, we contribute to human paleo-ecosystem modeling by applying ENM methods to an Australasian test case assessing Late Pleistocene human land preference in the context of both abiotic and biotic variables.

\subsection{ENM and its use in predicting hominin landscape preference}

ENMs have been used to assess both biogeographic patterns and species distributions throughout time (Maguire et al., 2015), as well as to find or reconstruct refugia (Waltari et al., 2007; Svenning et al., 2011; Gavin et al., 2014; Shi et al., 2014). Reconstructing refugia using ENM is of great interest to studies of human evolution and dispersal, as refugia have been considered a key element in hominin survival and dispersal (Dennell et al., 2011; Louys and Turner, 2012; Stewart and Stringer, 2012; Larick and Ciochon, 2015; Roberts and Petraglia, 2015; Bacon et al., 2018b). ENMs have been used to successfully identify Pleistocene refugia based on fossil occurrence data and extant environmental data in several plant species (Martínez-Meyer and Peterson, 2006; Gavin et al., 2014). ENM's have also been used to determine potential refugia for hominins in the Levant during marine isotope stage (MIS) 4 - providing evidence of ever changing green pathways in concurrence with theorized routes out of Africa and through south Asia (Field et al., 2007; Hughes et al., 2007; Svenning et al., 2011; Beeton et al., 2014; Jennings et al., 2015).

Fig. 1. Map of Australasian region denoting the 20 known "human land preference" sites used in ENM validation (see also Table 2). Arrows indicate long proposed "northern" and "southern" dispersal routes to Australia (Birdsell, 1977; Bowdler, 2010; Kealy et al., 2018; Norman et al., 2018). Dotted ellipse indicates the area of the proposed "Sundaland savannah corridor". This corridor has been considered to be a migration pathway for fauna during periods of climate change (Bird et al., 2005; Boivin et al., 2013; Bacon et al., 2018b).

Using ENM methods to combine abiotic data on long-term temperature and precipitation variation with abiotic landform data, species-interaction, and fossil occurrence data can create predictive outputs that map the occurrence probabilities for a species of interest. These fossil occurrence predictive maps can be combined with present-day data on erosion proxies and landscape accessibility to guide foot surveys for researchers interested in the past distribution of specific species. This way of combining ENM predictive output with local knowledge to increase the success of fossil prospecting missions has been applied successfully in Australian fossil survey for Eocene mammals (Block et al., 2016), suggesting applicability of these methods for future hominin fossil survey. 1.2. Including biotic data in species models

Abiotic variables can tell us much about how a species acts within its environmental niche and provide fundamental information about species range and tolerance. However, it is also important to consider how we may be able to incorporate biotic data (e.g., competition, distribution of vegetation 
and prey species, trophic interactions etc.) into these analyses. Interactions between species are an integral portion of modern conservation and niche conservatism studies (Fedriani et al., 2000; Linnell and Strand, 2000; Caro and Stoner, 2003; Palmer et al., 2003; Steinmetz et al., 2013) and many researchers have called for the inclusion of biotic data as a logical next step in species distribution methods (Guisan and Thuiller, 2005; Preston et al., 2008; Gavin et al., 2014; Maguire et al., 2015). However, incorporating biotic data into paleontological and paleoanthropological studies of land preference must account for additional hurdles, including collection bias of fossil data, differing site assemblages, as well as taphonomic bias related to size and preservation - a particular issue in temperate spaces (Von Endt and Ortner, 1984; Hanson and Buikstra, 1987; Lyman, 2014).

One potential way of including biotic interactions in ENMs is to include quantitative evidence of interspecific competition. Parallels between body size, encephalization, sociality, grouping and hunting behavior has been drawn between humans and other carnivores, particularly the social canids, suggesting it is possible to include humans as a "carnivore" in terms of comparing hunting behavior and resource use (Dunbar and Bever, 1998; Finarelli and Flynn, 2006; Treves and Palmqvist, 2007; Lewis, 2017). A competition index $(\mathrm{Cl})$ uses projected overlap of prey species between carnivores, accounting for group hunting methods to calculate estimated competition for prey resources on a scale of $0-1$. This can be done as a threshold of "maximum competitive pressure" for all of the predators in a guild or explored on a site by site basis. This method has been used successfully in Javan paleontological studies of carnivore guild dynamics (Hemmer, 2004; Hertler and Volmer, 2008; Volmer and Hertler, 2016), but has not yet been applied to humans.

Predator status is also a potentially complicating factor. Both modern human and other hominin relationships with local carnivore guilds have been studied in Europe (Walker and Churchill, 2011; Churchill, 2014) and Africa (Brantingham, 1998; Treves and Naughton-Treves, 1999; Treves and Palmqvist, 2007). In none of these cases were humans considered the apex or dominant species in the guild - meaning they were subject to some amount of interspecific competition for resources. This is of particular interest because of conservationist studies of Southeast Asian carnivore guilds which have shown that the tiger (the apex predator in this space) controls access to prey resources, and by proxy, the environments that lower ranked carnivores occupy. This has been shown specifically in the relationship between tigers and leopards in which tigers are reintroduced to protected natural areas and cause trophic cascades that push leopards to the fringes of the protected habitat (Odden et al., 2010; Harihar et al., 2011). If early humans dispersed into this guild and were not the apex predator, it is possible that competition with other carnivores influenced their position on the landscape and that we would expect humans to avoid areas with "high competition" for resources with highly ranked predators such as tigers and leopards.

\subsection{Paleoanthropological ENMs - Australasian test case}

Here, Southeast Asia includes the mainland countries east of India and south of China as well as all modern-day island nations in the Malay Archipelago. Papua New Guinea and Australia are also studied as part of this broader "Australasian" region through which humans dispersed in the Late Pleistocene (Fig. 1). We focus on Southeast Asia and Australia because of the unique mix of temperate and tropical environments in this region that were likely integral to human dispersal globally, given the evidence for widespread expansion of Homo sapiens into river basins in southern China during the Late Middle Pleistocene and Late Pleistocene (Wang, 2017; Bae et al., 2018). Throughout the Pleistocene, climatic fluctuation had a pronounced impact on temperature, sea levels, precipitation and vegetation in Asia (Heaney, 1991; Verstappen, 1997; Cook and Jones, 2012). Yet, even during glacial periods, rich tropical to sub-tropical evergreen forests and rainforests were present in small pockets in Southeast Asia on today's west Sumatran and west Bornean coasts. Between these forests, one hypothesis suggests a large area of grassland and open forest (the "Sundaland savannah corridor") extended through present day Thailand, Malaysia, east Sumatra and west Borneo from MIS 5 to MIS 2 (Bird et al., 2005; Cannon et al., 2009; Boivin et al., 2013; Bacon et al., 2018b), but see (Cannon et al., 2009). This corridor (Fig. 1) consisted of relatively open grassland and shrub environments, and, because of its borders to several different ecosystems (tropical rainforest, tropical evergreen forest, and dry open deciduous forest to the north), was a prime site of major faunal exchanges and therefore a likely migration route for humans as well (Tougard, 2001; Gathorne-Hardy et al., 2002; Tougard and Montuire, 2006; Louys, 2014). Australasia became a likely place for hominin dispersal in the Late Pleistocene, likely because of drastic geographical changes that made this space largely temperate and resource dense.

There has been debate about the route that humans used to get to Australia since the 1970's - particularly whether humans would have used a northern route through Borneo, Sulawesi, the Talaud Islands, and Papua New Guinea, or a more southern route through Sumatra, Java, Flores and East Timor (Birdsell, 1977), and recent predictive models based on "least cost pathway" analysis provide evidence for both routes (Kealy et al., 2018; Petraglia et al., 2019).

The northern route maintained open savannah and riverine complexes (Heaney, 1991; Bird et al., 2005; Bacon et al., 2018a), and use of this route would suggest human migration preference for savannah environments, large prey species, moderate rainfall, and competitive pressure from pack carnivores. The southern route, alternatively, was primarily denser tropical forest ecosystems (Kershaw et al., 2001; Gathorne-Hardy et al., 2002; Summerhayes et al., 2016) and use of this route might suggest migratory preference for forested/coastal environments, heavy rainfall, and interactions with primarily ambush carnivores. The environmental variability of this longtemperate Australasian region provides a prime location for an ENM test case of human land preference.

Here, we use ENM to predict land preference for humans in a Late Pleistocene Australasian test case. We assess human land preference in this region in the context of both abiotic (mean annual temperature and precipitation, slope as a type of landform data) and biotic variables (competition) during the Last Glacial Maximum (26.5-19 ka) (Clark et al., 2009). This was a time of increased climate instability globally, but in a region that maintained temperate and tropical ecosystems, it is possible that environmental variables that have successfully predicted hominin land preference in other regions may not perform well in this space. We expect that traditionally used abiotic variables (here, mean average temperature and precipitation) will be relatively poor predictors of human land preference in this longstanding temperate ecosystem as it would be expected that humans would disperse through warmer and wetter areas. We expect that abiotic landform data (here, elevation calibrated downward slope as a proxy for terrain "ruggedness"), as well as biotic data on human-carnivore competition for prey resources will be better predictors of human land preference as they may hold more predictive power in a landscape with mild temperatures and high rainfall. This would align with expectations that humans would disperse more easily through lower/moderately sloped areas, and areas with low competition. We use ENM on both large-scale (all of Australasia) and localizedscale (mainland Southeast Asia, i.e. Laos and Vietnam) analyses to determine if these predictor variables function similarly on different geographic scales. This question of scale is key for providing contextualizing information useful to both the overall debate on "preferred" human dispersal pathways to Australia as well as providing local predictive maps that could be used to supplement ongoing fossil foot-survey.

It is worth noting that there are limitations and assumptions in all computational modeling, and paleo-ENM highlights some of these assumptions associated with assigning data to the model. For example, a key caveat of paleo-ENM is creating biased distribution estimates because of improper identification of species that look similar (Lozier et al., 2009). While this may be an issue for few sites in Indonesia which maintain both Homo erectus and Homo sapiens assemblages (Rizal et al., 2019), based on the dating 
and morphology of fossil assemblages and the unique lithic assemblages, we can be confident that we are in fact imputing accurate human presence sites into the model. An additional concern is that ENMs of glacial refugia tend to show a consistent southward bias (Davis et al., 2014), however, by calibrating the ENM with fossil presence data, this bias can be somewhat mitigated. Additionally, in a temperate test case which maintained rainforest refugia in glacial periods, this bias may be somewhat mitigated. ENM programs are designed to give results no matter what data is given to them, thus it is especially important that climate variables are picked because they may actually have an impact on niche construction during the time period of interest - in this case Late Pleistocene Australasia - to avoid biasing the model output (Varela et al., 2011). Because of this, testing baseline variables (e.g., variations in temperature, precipitation) that are most often used in ENM studies is even more vital when approaching questions about how species here, humans - move in different environmental contexts.

\section{Materials and methods}

\subsection{Abiotic data for ENM modeling}

Abiotic variables common to paleoclimate reconstructions of human land preference were employed here - specifically, mean annual temperature and precipitation, and landform data (slope as a proxy for terrain "ruggedness"). These variables were quantified for Southeast Asian and Australian landscapes during the time period of the Last Glacial Maximum (26.5-19 ka). Mean annual temperature was quantified using Sea Surface Temperature (SST, $n=103$ locations), a multi- proxy reconstruction that has shown promise in capturing tropical climate variability in ENM projections (Furtado et al., 2009) from planktonic and benthic foraminifera reconstructions (Calvo et al., 2007; Crundwell et al., 2008; Saikku et al., 2009; Ford et al., 2015) for the Last Glacial Maximum and showed little variation. $\delta^{18} \mathrm{O}$ speleothem and sea core data $(n=$ 1751 locations) were mapped into a single layer reflecting finer grained detail in mean annual precipitation data (Cai et al., 2010) using the following data (Partin et al., 2007, 2015; Mohtadi et al., 2010, 2014; Ayliffe et al., 2013; Carolin et al., 2013; Denniston et al., 2013a, 2013b; Gibbons et al., 2014). Additionally, terrain "ruggedness" (see Whittey, 2017) was quantified using downward slope data (in degrees) using a 1-degree resolution, digital elevation model across the region of interest (ESRI Terrain slope data). Slope was chosen specifically as a predictor variable because hill shade (how the sun interacts with the landscape) and aspect (directional data regarding slope; e.g. northerly slope) were not considered to be as likely of a potential barrier for human land preference compared to the steepness of the landscape. Additionally, terrain slope has a long history as an important variable in paleolithic analyses of human skeletal variation (Marchi, 2008; Higgins and Ruff, 2011; Higgins, 2014; Wall-scheffl, 2014; Whittey, 2017; Zachwieja and Shackelford, 2014, 2019) and therefore likely influenced human mobility in a broad sense as well. While slope does not capture all of the variation in landform data that may affect human mobility, it was used here as a first step in introducing landform data into human specific paleoecosystem modeling. All abiotic variables included in ENM analysis were retrieved from open source databases including the NOAA paleoclimatology database (ncdc.noaa.gov/data- access/paleoclimatologydata/datasets) and the ESRI ArcGIS Living Atlas (https://livingatlas.arcgis.com/en/).

\subsection{Biotic data in $E N M$}

We quantified biotic data for ENM using a competition index $(\mathrm{Cl})$, which assesses calculated potential competition for resources in the Late Pleistocene Southeast Asian carnivore guild (including humans) in the Annamite mountains in northern Laos and Vietnam to obtain a picture of the predators and prey species on the landscape. The $\mathrm{Cl}$ is concerned with broad comparisons of species presence across different environments, rather than a direct analysis of faunal abundance by site. Because of this, though we are using assemblages from specific fossil bearing sites we avoid direct comparison of sites with different formations and instead use a faunal presence approach to confirm what species were in this space during the time period of interest.

Competition between humans and carnivores (tigers, leopards, dholes, hyenas, and Asiatic golden cats) was quantified for a subset of five sites in northern Laos and Vietnam in the Annamite mountain chain using paleontological fossil data (Table 1, see Fig. 6 for map of site locations) to create a Competition Index $(\mathrm{Cl})$. This general region has been known to preserve Late Pleistocene modern human presence with fossils or archaeological assemblages (Demeter et al., 2017; Shackelford et al., 2018) as well as maintain Late Pleistocene faunal assemblages that are relatively similar across time and space. In fact, most fauna associated with Late Pleistocene sites in Australasia, still maintain species presence in this region today (Bacon et al., 2006, 2008a; 2008b, 2011; 2015), suggesting that these five sites would provide good information on faunal presence in this region.

$\mathrm{Cls}$ are estimates of maximum competition (on a scale of $0-1$, where 0 is no prey overlap and no competition, and 1 is total prey overlap and constant competition) between predators sharing an environmental niche based on prey preferences and body mass estimates (Hemmer, 2004; Hertler and Volmer, 2008). Prey that can be successfully utilized by a predator is a function of predator mass and is well established in the literature (Earle, 1987; Hemmer, 2004; Hertler and Volmer, 2008). Mass-class estimates for prey species (following Hemmer, 2004) that were present at these sites were calculated from the literature (Table 2) and carnivore mass was calculated using lower first molar lengths and family-specific regression equations (Van Valkenburgh, 1990). We attempt to avoid some bias of fossil faunal abundance (related to calculation of the $\mathrm{Cl}$ ) through comparisons with modern correlates in conjunction with MNI, NISP, and use of relative abundance by taxa/size level rather than species for prey (Heaney, 1986; Meijaard, 2003; Mudar and Anderson, 2007; Lewis, 2017). The patterns of accumulation and dating of the sites used for $\mathrm{Cl}$ analysis are well documented, and the assemblages represent similar species abundances as modern faunal communities in Southeast Asia since fauna have remained conserved since the Late Pleistocene (Bacon et al., 2008b, 2015). M1 length measures of isolated teeth were used to calculate predator mass estimates for the $\mathrm{Cl}$ and to avoid potential confusion with minimum number of individuals and unassociated bones following previous studies (Van Valkenburgh, 1990; Hemmer, 2004; Hertler and Volmer, 2008). 
Table 1

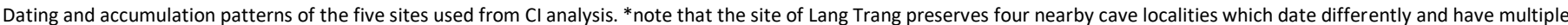

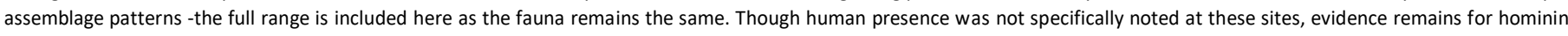

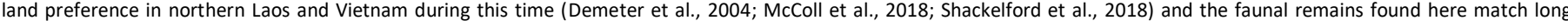

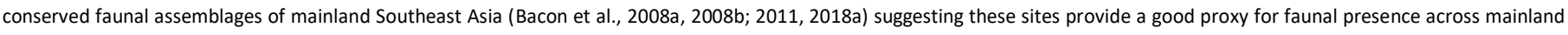
Southeast Asia at this time.

\begin{tabular}{|c|c|c|c|}
\hline Site & Date & Accumulation & References \\
\hline Tam Hang South & $94-60 \mathrm{ka}$ & $\begin{array}{l}\text { Endokarstic deposit. Not associated with Holocene human } \\
\text { burials }\end{array}$ & Bacon et al. (2008), 2011; 2015 \\
\hline Nam Lot & $86-72 \mathrm{ka}$ & Predatory/hyena accumulation/endokarstic deposit & Bacon et al. (2015), 2018a \\
\hline Duoi U’Oi & $70-60 \mathrm{ka}$ & Predatory/Homo sp. accumulation/endokarstic deposit & Bacon et al. (2008), 2015 \\
\hline Lang Trang* & $\begin{array}{l}\text { Unpublished ESR dates } \\
\text { 385-185 ka } \\
\text { Published at } 80 \text { ka }\end{array}$ & Breccia deposit/possible Homo sp. occupation & $\begin{array}{l}\text { Ciochon and Olsen 1991; Long et al., 1996; Marwick, 2008; Ciochon } \\
\text { (2010) }\end{array}$ \\
\hline Tham Om & $250-125 \mathrm{ka}$ & Possible Homo sp. occupation & Kha 1975, 1977; Olsen and Ciochon (1990); Cuong (1992) \\
\hline
\end{tabular}

\section{Table 2}

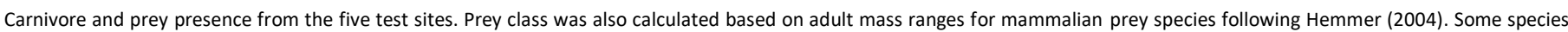

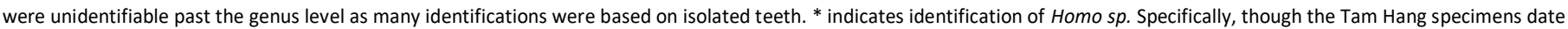

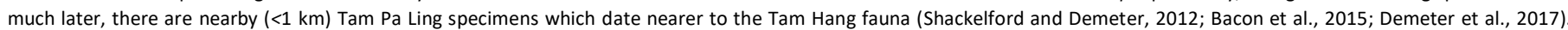
Species ID's were confirmed by A. J. Zachwieja following (Bacon et al., 2008a, 2011).

\begin{tabular}{|c|c|c|c|c|c|c|}
\hline Presence of Carnivores & Tam Hang, Laos & Nam Lot, Laos & Duoi U’Oi, Vietnam & Lang Trang, Vietnam & Tham Om, Vietnam & \\
\hline Cuon alpinus & $x$ & $x$ & $\mathrm{x}$ & $\mathrm{x}$ & $x$ & \\
\hline Panthera pardus & & & $x$ & $x$ & & \\
\hline Panthera tigris & $x$ & & $\mathrm{x}$ & $\mathrm{x}$ & $x$ & \\
\hline Crocuta/H. brevirostris & & $x$ & & & & \\
\hline Arctonyx collaris & & & $x$ & $x$ & $x$ & \\
\hline Ursus thibetanus & $x$ & $x$ & $x$ & $x$ & $\mathrm{x}$ & \\
\hline Felis temmicki/sylvestris & & & & $x$ & $x$ & \\
\hline Homo sp. & $x^{*}$ & $x^{*}$ & $x$ & $x^{*}$ & $\mathrm{x}^{*}$ & \\
\hline Presence of Prey & Tam Hang, Laos & Nam Lot, Laos & Duoi U'Oi, Vietnam & Lang Trang, Vietnam & Tham Om, Vietnam & Prey class (adult) \\
\hline Macaca mulatta & $\mathrm{x}$ & $x$ & $\mathrm{x}$ & $\mathrm{x}$ & & $2 c$ \\
\hline Hylobates lar & $x$ & & $x$ & $x$ & $x$ & $2 c$ \\
\hline Bovidae sp. & $x$ & $x$ & $x$ & $x$ & & $4 b-5 a$ \\
\hline Cervus unicolor & $x$ & $x$ & $x$ & $x$ & $x$ & $4 a-4 b$ \\
\hline Capricornus sumatrensis & $x$ & $x$ & $x$ & $x$ & & $3 b-3 c$ \\
\hline Muntiacus muntjak & $x$ & $x$ & $x$ & $x$ & $x$ & $3 a$ \\
\hline Sus scrofa & $\mathrm{x}$ & $x$ & $\mathrm{x}$ & $\mathrm{x}$ & & $3 c-4 a$ \\
\hline Rhinoceros uniconis & $x$ & $x$ & $x$ & $x$ & $x$ & $5 a$ \\
\hline Rhinoceros sumatrensis & $x$ & $x$ & $x$ & $\mathrm{x}$ & & $4 c$ \\
\hline Tapiris indicus & $x$ & $x$ & $x$ & $x$ & & $4 b$ \\
\hline Stegodon $s p$ & $\mathrm{x}$ & $x$ & & $\mathrm{x}$ & $x$ & $5 a-5 b$ \\
\hline Hystrix indica & $\mathrm{x}$ & $x$ & & $\mathrm{x}$ & & $3 a$ \\
\hline Pongo pygmaeus & $x$ & $x$ & & $x$ & $x$ & $3 b-4 a$ \\
\hline Megatapirus agustus & $\mathrm{x}$ & & & $x$ & & $4 c$ \\
\hline Colobinae sp. & & & & $x$ & & $2 c-3$ \\
\hline Elephus maximus & & & & & $\mathrm{x}$ & $5 b-5 c$ \\
\hline
\end{tabular}

$\mathrm{MNI}$ and species counts were included from fauna from five sites from Laos and Vietnam. Lao sites included Tam Hang South and Nam Lot; Vietnamese sites included Duoi U'Oi, Lang Trang, and Tham Om. Though these sites did not preserve human fossil presence (there are some uncertainties regarding the classification of primate teeth at Tham Om and Lang Trang) (Olsen and Ciochon, 1990; Cuong, 1992; Marwick, 2009; Ciochon, 2010), they are in a 
region well known to preserve sites bearing Late Pleistocene Human remains (Demeter et al., 2017), suggesting this area of the Annamite mountains preserved modern human occupations and that humans were on the landscape with these fauna at this time. Full details of context and dating of the faunal assemblages used in the analysis can be found in Table 1.

Regarding faunal presence, the primary prey species in these Southeast Asian fossil assemblages are cervids, suids, and bovids. However, many sites in the Annamite mountains maintain a large mass range of prey species from small rodents to stegodons and elephants (Bacon et al., 2004, 2006; 2008b, $2011 ; 2015)$. While the faunal assemblages at these sites date from the Middle Pleistocene to the Late Pleistocene, the Sundaland region faunal complexes have remained relatively stable until modern times (minus the extinction of the stegodon and megatapir, as well as the disappearance of the spotted hyena from Southeast Asia), suggesting these faunal complexes represent a clear picture of the Southeast Asian food webs from the Late Pleistocene onwards (Bacon et al., 2008b, 2015). A full list of the species present at the five test sites, as well as their corresponding "prey mass class" (Hemmer, 2004) can be found in Table 2 .

$\mathrm{Cl}$ was calculated following previous studies in which carnivores are compared by the mass of the prey they can reasonably choose to eat, and those they usually focus on (Earle, 1987; Hemmer, 2004; Hertler and Volmer, 2008). The amount of overlap between prey species utilized by the carnivores in question can be compared. More prey-choice overlap equals higher competition for resources. $\mathrm{Cl}$ was calculated using the ratio of the overlapping prey mass classes shared by two species as compared to their overall prey choice ranges (see equation below).

$C \mid x \rightarrow y=($ Overlapping classes species $x$ on $y) /($ Total classes species $x+y)$.

Overall competitive estimates from 0 (no competition) to 1 (full prey overlap, likely extreme competition) were compiled on both a site- specific basis and as a regional "maximum" and were included to represent a biotic variable in ENM. ENMs including this biotic component were restricted to northern Laos and Vietnam, as interpolating beyond the bounds of our biotic data would be irresponsible and therefore were not validated against all 20 "known human preference" sites (Table 3). However, this test represents the first-time biotic information has been included in any ENM predicting human land preference in paleoanthropological research.

\subsection{Methods}

Three iterative ENM models were compiled and run using the open source Maxent software for modeling species niches and distributions with the following variables (Phillips et al., 2017):

1. Model 1: mean annual temperature and precipitation for the LGM

2. Model 2: Model $1+$ slope

3. Model 3: Model $2+\mathrm{Cl}$ (modeled for only northern Laos and Vietnam)

ArcGIS Pro was used to clip abiotic variables to the same geographic boundaries as well as to interpolate trends from point data of each variable using the inverse distance weighting (IDW) technique. Layers were then exported as.asc files to be used in the Maxent modeling program (Phillips et al., 2017), which is a machine learning approach that uses "maximum entropy" to find the best fitting target distribution given the presence of expected climatic values. The Maxent ENM program was chosen specifically for this test case because of its usefulness in creating both accurate and precise predictions with small sample sizes (as compared to GARP, BIOCLIM, generalized linear models, and others) (Phillips et al., 2004; Townsend Peterson et al., 2007; Costa et al., 2010; Tarkesh and Jetschke, 2012; Block et al., 2016). Additionally, Maxent creates predictive models using only species presence data (as opposed to including absence data as well). Since we cannot be sure of human absence anywhere on the landscape and maintain only limited presence data based on fossil and archaeological evidence, Maxent proved to be the best choice for these ENM simulations. In a direct comparison of GARP and Maxent using these data, Maxent models far outperformed GARP models (Zachwieja and Shackelford, 2018). 
maintain the most comprehensive indicators of human presence on the landscape (Bible and Peterson, 2018).

\begin{tabular}{|c|c|c|c|c|}
\hline Site Name & Site location & Age (BP) uncalibrated & C14/OSL calibrated dates & References \\
\hline Nombe & Papua New Guinea & $25,000-14,700$ & $30,850-17,270$ & Mountain 1991 \\
\hline Toe Cave & Papua New Guinea & $25,920 \pm 180$ & $31,040-30,350$ & Clarke 2007; Pasveer 2004 \\
\hline Matenbek & $\begin{array}{l}\text { Bismarck } \\
\text { Archipelago }\end{array}$ & $20,430 \pm 180$ & $24,400-23,440$ & Allen 1989 \\
\hline Pamwak & $\begin{array}{l}\text { Bismarck } \\
\text { Archipelago }\end{array}$ & 20,900 & $>25,860$ & Spriggs 2001 \\
\hline Kilu Cave & $\begin{array}{l}\text { Bismarck } \\
\text { Archipelago }\end{array}$ & $28,740 \pm 280$ & $33,365-31,690$ & Wickler1990, 2001 \\
\hline Tham Lod & Thailand & $35,000 \pm 3000$ & & Chitkament et al., 2015 \\
\hline Lang Rongrien & Thailand & $43,000-10,000$ & & Anderson 1997, Mudar and Anderson (2007) \\
\hline Moh Khiew & Thailand & $25,000 \pm 600$ & & Dennell and Porr 2012 \\
\hline Tam Hang & Laos & & $94,000-3000$ & Bacon et al. (2015), Shackelford and Demeter (2012), McColl et al. (2018) \\
\hline Wadjak & Java & $<12,000$ & & Dennell and Porr 2012 \\
\hline Tabon Cave & Philippines & $47,000-31,000$ & & Dennell and Porr 2012 \\
\hline Lake Mungo & Australia & & $40,000-24,700$ & $\begin{array}{l}\text { Brown 1992; Bowler 1970; Bowler and Price 1998; Oysten 1996; Bowler 2003; } \\
\text { Thorne } 1999\end{array}$ \\
\hline Kow Swamp & Australia & & $\begin{array}{l}22,000-19,000 \text { OSL } \\
13,900-9590 \text { C14 }\end{array}$ & Brown 1992; Stone and Cupper 2003 \\
\hline Nacurrie & Australia & & $11,440 \pm 160$ & Brown 1992 \\
\hline Keilor & Australia & & $12,000 \pm 100$ & Brown 1992 \\
\hline Coobool Creek & Australia & $14,300 \pm 1000$ & & Brown 1992; Bowdler 1992 \\
\hline Liang Lembudu & Indonesia (Aru Islands) & & 28,000 & O'Connor 2002a \\
\hline Lene Hara Cave & Indonesia (East Timor) & $35,000-30,000$ & & O'Connor 2002b \\
\hline Wanda Site - core 3 & Indonesia (Sulawesi) & & $14,560 \pm 130$ & Hope 2001 \\
\hline Lua Meko Cave & Indonesia (Roti) & 24,000 & & Mahirta 2003, 1999 \\
\hline
\end{tabular}

Sites used in ENM analysis listed by location with un-calibrated or calibrated dates as well as references.

Using Maxent, ENMs of multiple variables were fit to our validation data, which included human occupation sites $(n=20)$ across Australasia that maintained fossil or archaeological human presence (Table 3). The way human occupation sites are included in the model can be summarized in two categories, model training sites and model testing sites. Model training sites consist of securely dated human occupation sites along the two likely geographic routes to Australia: a northern, inland route through Borneo, Sulawesi, the Talaud Islands, and Papua New Guinea or a more southern, coastal route through Sumatra, Java, Flores and East Timor.

Subsets of these sites are then randomly included in the model to "train" it to focus on the type of environments at sites with known dates. Testing sites can be described as random subsets of the total sites (excluding training data) that are compared to the model after it runs. If these sites fit within the scope of the environments proposed by the model as favorable, the model is considered successful. If they do not, the model must be recalibrated. This is done in multiple iterations to train the model to the most comprehensive understanding of known human land preference before creating a projection of potential human land preference if humans were constrained by the environmental variables at play (in this case, temperature, precipitation, terrain, and $\mathrm{Cl}$ ). Abiotic models were validated against 20 known human preference sites (indicative of both proposed dispersal routes) based on fossil, occupation, or archaeological assemblages indicating human presence (Fig. 1, Table 3). Known human "land preference" sites for model validation purposefully included all potential indicators (fossil or archaeological) to
Jackknife tests (a type of leave-one-out cross validation) and area under the curve (AUC) statistics were then used to assess the overall fit of the model to the testing data based on a subset of randomized training data and to indicate which environmental variable had the most influence on the individual model. Disparities between models suggest that, as in any other analysis, the coverage and accuracy of an ENM relies largely on the data entered into the model. Luckily, the coverage of paleoclimatology databases such as NOAA is vast ( 1$2 \mathrm{ka}$ time-slices over the past $\sim 80 \mathrm{ka}$ or so). It is important to import data from as many paleoenvironmental databases as possible to obtain a wide spread of climate interactions throughout time. This provides the program with the most environmental coverage for the variables we are testing (Russell and Bijaksana, 2012). Here, the inclusion of several different types of data from 11 studies allows for an initial assessment of what kind of variables may be important in a temperate context of human evolution and dispersal and may suggest further variables for study.

\section{Results}

\subsection{Model 1: mean annual temperature and precipitation for the LGM}

ENM layers of mean annual temperature and precipitation reflect a relatively temperate landscape for Southeast Asia and Australia during the Last Glacial Maximum. Temperature gradients suggest hotter northern regions and cooler regions in South Australia, but all temperatures are well within levels for human survival and occupation (12.67-24.02 ${ }^{\circ} \mathrm{C}$ ) (Fig. 2). Precipitation 
estimates based on $\delta^{18} \mathrm{O}$ show a relatively wet region, particularly in what is now island Southeast Asia (similar to (Caley et al., 2014)), though again estimates of rainfall across the entire region reflect temperate conditions well within the realm of human livability $\left(\delta^{18} \mathrm{O}\right.$ readings between -7.55 and -1.23 ) (Fig. 3). Maxent output shows that this model fits well to randomized known human occupation data ( $A \cup C=0.835$, random prediction would be $A \cup C=0.5$ ), and jackknife (leave one out) validation testing shows that temperature pulls the model (regularized training gain 1.3/1.38) (Table 4). Regarding favorability of human occupation, much of the region is considered "favorable" for human occupation at this time using just temperature and precipitation as predictors (between 0.46 and 0.92 ) and mapped output is not useful for determining fine or broad scale patterns of land preference.

\subsection{Model 2: model $1+$ slope}

The second model used mean annual LGM temperature and precipitation data from Model 1 with the addition of quantified "terrain ruggedness" data (elevation calibrated slope) over the same geographic boundaries. Slope ranged from 0 to $27^{\circ}$ over the modeled area (Fig. 4). Maxent output showed that this model fits better than Model 1 (AUC $=0.924$ ) and the projected favorability is much more localized with higher favorability in mainland southeast Asia and island southeast Asia, particularly Indonesia (generally $0.85-1$ ), though overall estimates range from 0 to 1 (Fig. 5). In this iteration, slope is the primary influence on the model (regularized training gain $0.68 / 0.92$ ), followed by temperature (Table 5 ).

3.3. Model 3: localized analysis of abiotic and biotic variables - Laos and vietnam

Competition index data (where 0 is no prey overlap/no competition and 1 is $100 \%$ prey overlap indicating very high competition) included maximum calculations for each species (Table 6) as well as individual site-specific estimates for northern Laos and Vietnam (Table 7). Generally, humans' biggest competitors were other medium size prey specialists including the dhole ( $\max$ $\mathrm{Cl}: 0.5)$, hyena ( $\max \mathrm{Cl}: 0.6)$, and leopard ( $\max \mathrm{Cl}: 0.66$ ), though they did likely experience much smaller amounts of competition from tigers ( $\max \mathrm{Cl}$ : 0.33 ) and Asiatic golden cats (0.11) and we would expect that humans would avoid areas of high competition. Additionally, hunting type (solo ambush vs. group hunting) did affect competitive estimates, but group hunting alone was used here, as we can assume that humans were often using cooperative hunting strategies based on faunal assemblages of prime age prey (Bacon et al., 2018a; Wattanapituksakul et al., 2018). Site specific estimates (Table 7) were included as a biotic layer in Model 3's ENM (Fig. 6).

All variables from Model 2 (mean annual temperature and precipitation, slope) were also used in this ENM, which focused geographically on Laos and Vietnam. Maxent output did not show a fit comparable with

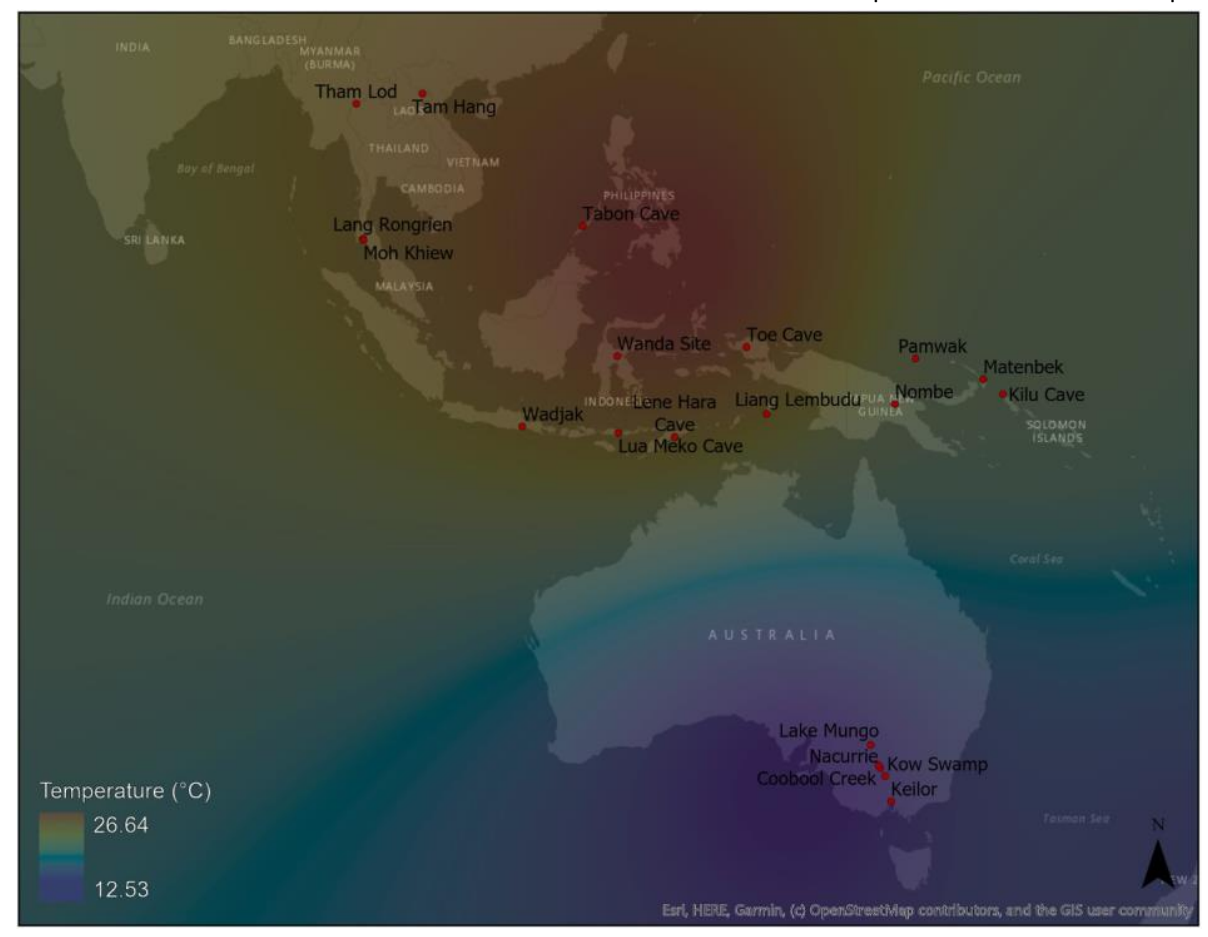

Fig. 2. Temperature gradient interpolated from point data for study region during the Last Glacial Maximum. Cooler colors represent cooler temperatures and warmer colors, warmer temperatures. All temperatures across the region of interest were estimated to be between 12.53 and $26.64{ }^{\circ} \mathrm{C}$. (For interpretation of the references to color in this figure legend, the reader is referred to the Web version of this article.) 


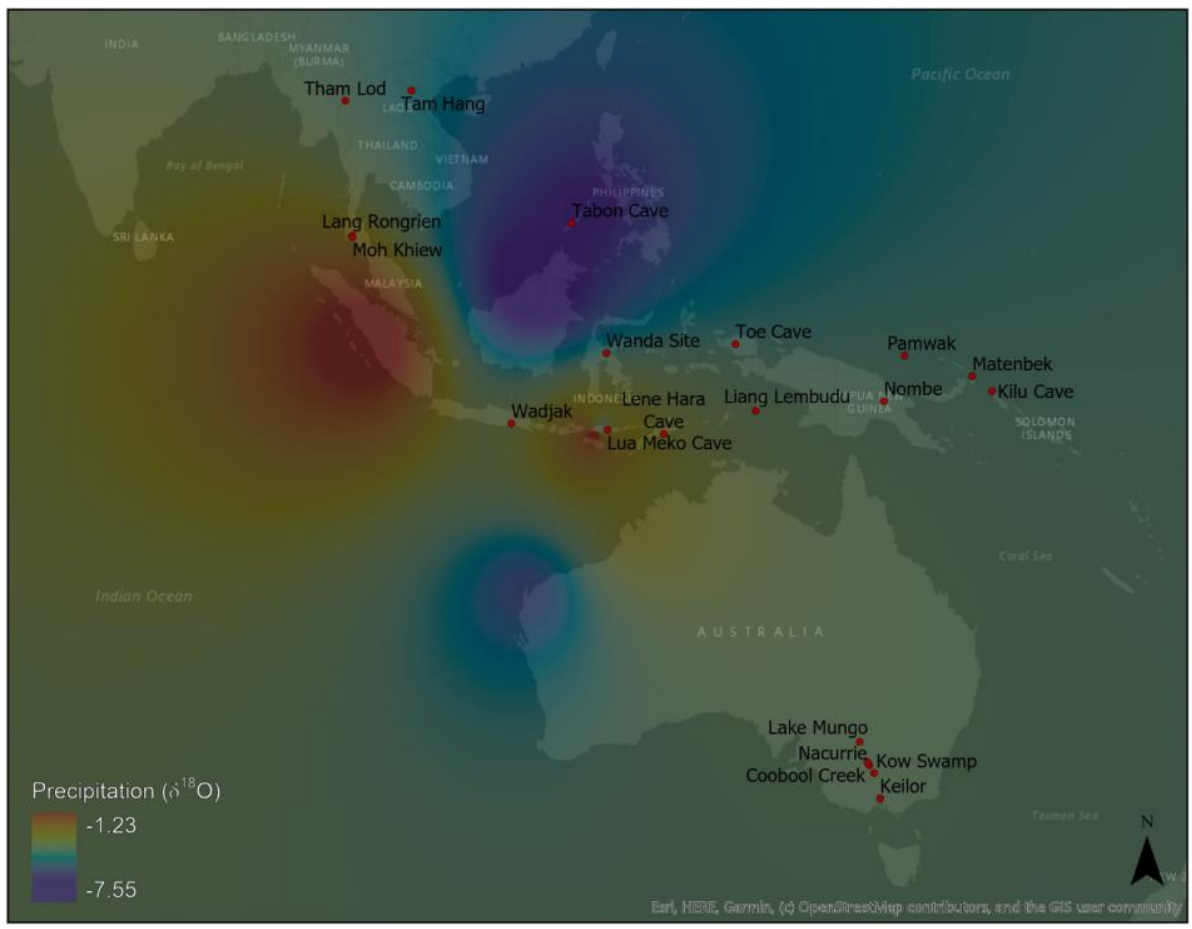

Table 4

Table of leave-one-out cross validation (jackknife) testing of variable importance for Model 1 -Temperature and Precipitation. Resulting data reflects the model training gain with estimated contribution and importance of each variable in providing ENM output. In Model 1 temperature pulls the model predictions.

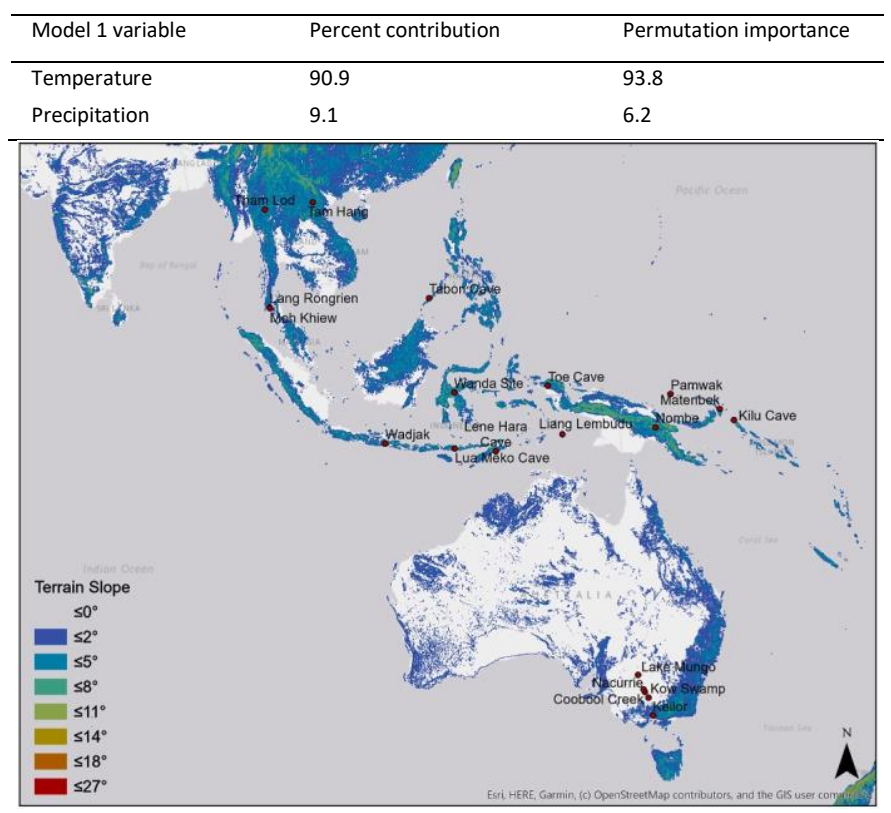

Fig. 4. Calculated terrain slope across the modeled area from ESRI as an approximation of Last Glacial Maximum terrain slope. Slopes were between 0 and $27^{\circ}$ where warmer colors represent steeper slopes than cooler colors. This environmental layer was then added to Model 2 ENM with the addition of temperature and precipitation. (For interpretation of the references to color in this figure legend, the reader is referred to the Web version of this article.)

the previous two models $(A \cup C=0.695)$. Of the included variables, temperature pulled the model in this iteration, followed by precipitation, then slope. Cl did not seem to contribute to model estimates of favorability (Table 8). Estimated favorability was extremely generalized, with much of the study area between
Fig. 3. Precipitation gradient interpolated from point data for study region during the Last Glacial Maximum. Cooler colors represent less precipitation and warmer colors, more precipitation. Isotope values between -1.23 and -7.55 all suggest moderate to high levels of precipitation and therefore relative lack of water stress. Lower isotope values indicate higher rainfall. (For interpretation of the references to color in this figure legend, the reader is referred to the Web version of this article.)

0.38-0.69 in terms of potential favorability for human land preference at this time using all the described variables (Fig. 7).

\section{Discussion}

We used ENM in a test case in Late Pleistocene Australasia to predict human land preference in this region using abiotic and biotic data. We used ENM on both large-scale (all of Australasia) and localizedscale (mainland Southeast Asia - Laos and Vietnam) analyses to determine if scale influenced the predictive output of ENM. This question of scale is key for providing contextualizing information useful to both the overall debate on "preferred" human dispersal pathways to Australia (e.g., a northern route or southern route to Australia) as well as providing local predictive maps that could be used to supplement ongoing fossil foot- survey. It is possible that humans dispersing through this region may have preferred specific ecosystems as dispersal or migration pathways, since modern human studies have shown that humans move in response to environmental stressors predictably to increase habitat quality and resource availability - both of which are functions of discrete variables related to climate and environment (Morgan, 2009; Williams et al., 2010). However, it is also possible that our assumptions of the environmental pressures facing humans during their dispersal in Australasia is based on our understanding of human dispersal and ENM land preference predictions in glacial climates, and we lack the temperate ENM context to know if these assumptions are valid. Therefore, we analyzed multiple ENM models of human land preference using traditional abiotic variables (mean annual temperature and precipitation) as well as landform data (slope) and biotic competition data.

We expected that slope and competition would be better predictors in temperate Australasia, and that the long used ENM variables (here mean annual temperature and precipitation) would be poorer predictors. While slope proved to be the most highly predictive variable used in these ENMs, many of these other expectations were not supported. 


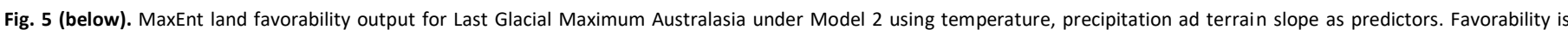

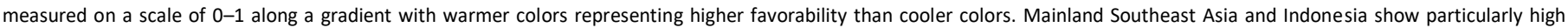
favorability estimates. (For interpretation of the references to color in this figure legend, the reader is referred to the Web version of this article.).

Temperature and precipitation produced models that generally fit well (showing they are accurate predictors), though these high AUC values were paired with very poor on the ground predictive estimates (i.e., the whole landscape was considered "preferred" by humans and therefore there was no discrimination to the prediction maps - leading to high AUCs, but relatively useless maps). The model including slope performed best in terms of accuracy (high AUC value) and precision (useful human land preference maps), though were always adequate for human survival in this space and, therefore would not be a good predictor of land preference, matching our expectations. This outcome also reflects inconsistencies in comparing European and Asian studies of human land preference using ENM, providing evidence that studies applying ENM in temperate regions may need to account for very different variables than those successful at predicting human land preference in other environments. In a cooler, more arid space in which extreme temperature or

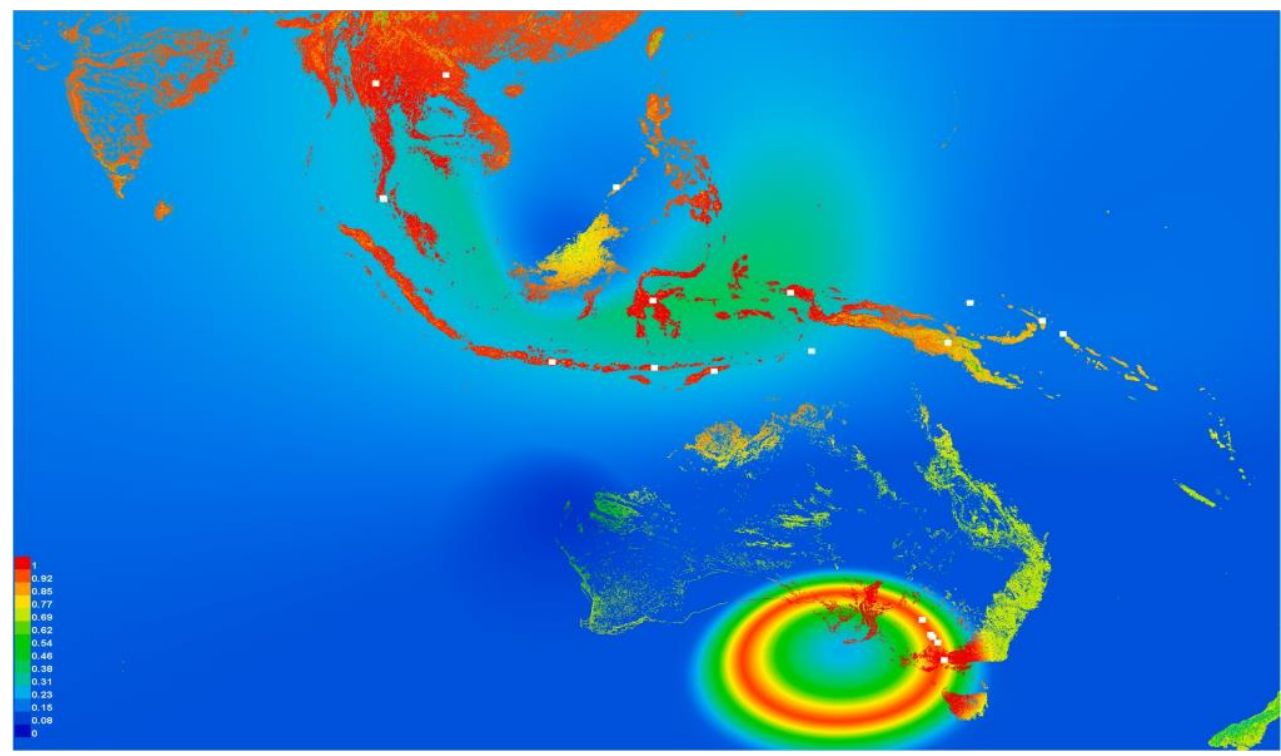

models suggested moderately sloped areas (above $15^{\circ}$ ) to be preferred by humans. Biotic competition data did not contribute to localized land preference models, and abiotic data were considered most important for these data, though they had both low accuracy and low precision. Overall, abiotic variables maintained their importance in this temperate region, but we suggest that temperature and precipitation estimates should be combined with additional abiotic and biotic data to unpack the variability inherent in human land preference in a temperate space and to further assess landform data as the best predictor of human land preference in this Australasian test case.

Our first ENM model focused specifically on two of the variables considered most important (mean annual temperature and precipitation) for predicting human land preference in the few ENM analyses of hindcasting human land preference in paleoanthropology (Barton et al., 2011; Beeton et al., 2014; Rodríguez et al., 2015; Glantz et al., 2018). Using random iterations of the 20 human validation sites, Model 1 was considered favorable ( $A \cup C=0.835$ ) as compared to random ( $A \cup C=0.5$ ), suggesting that this model was of good fit to our data. Despite the AUC of this model, favorability estimates of human land preference were between 0.46 and 0.92 signifying that over $50 \%$ of the time we could expect to find humans throughout the tested area. This result is an indication of a discrepancy between the accuracy and precision of our first model in a temperate space. While the model's relatively high AUC suggests it has returned an accurate model, the broad favorability tells us that this model is not precise enough to provide anything specific about human land preference - and therefore, is not informative enough for our purposes and does not provide any reliable evidence for land preference or either potential dispersal route. Because Australasia and Southeast Asia in particular was largely temperate even during glacial periods (Kershaw et al., 2001; GathorneHardy et al., 2002), it is quite likely that temperature and precipitation levels precipitation strongly influence the mortality of migrating humans, these variables have proven very informative; however, they did not provide a nuanced picture of human land preference in this Southeast Asian test case.

Our second model maintained mean annual temperature and precipitation as predictive layers, but further included slope as a proxy for terrain ruggedness following Whittey (2017). Particularly in mainland Southeast Asia, karstic mountains are ubiquitous (Duringer et al., 2012) and would certainly create, if not a barrier, then a variable that must be overcome to develop land preference strategies within this space. What is today island Southeast Asia also maintains mountains that have known Pleistocene human occupation (e.g., Barsian Mountains in 


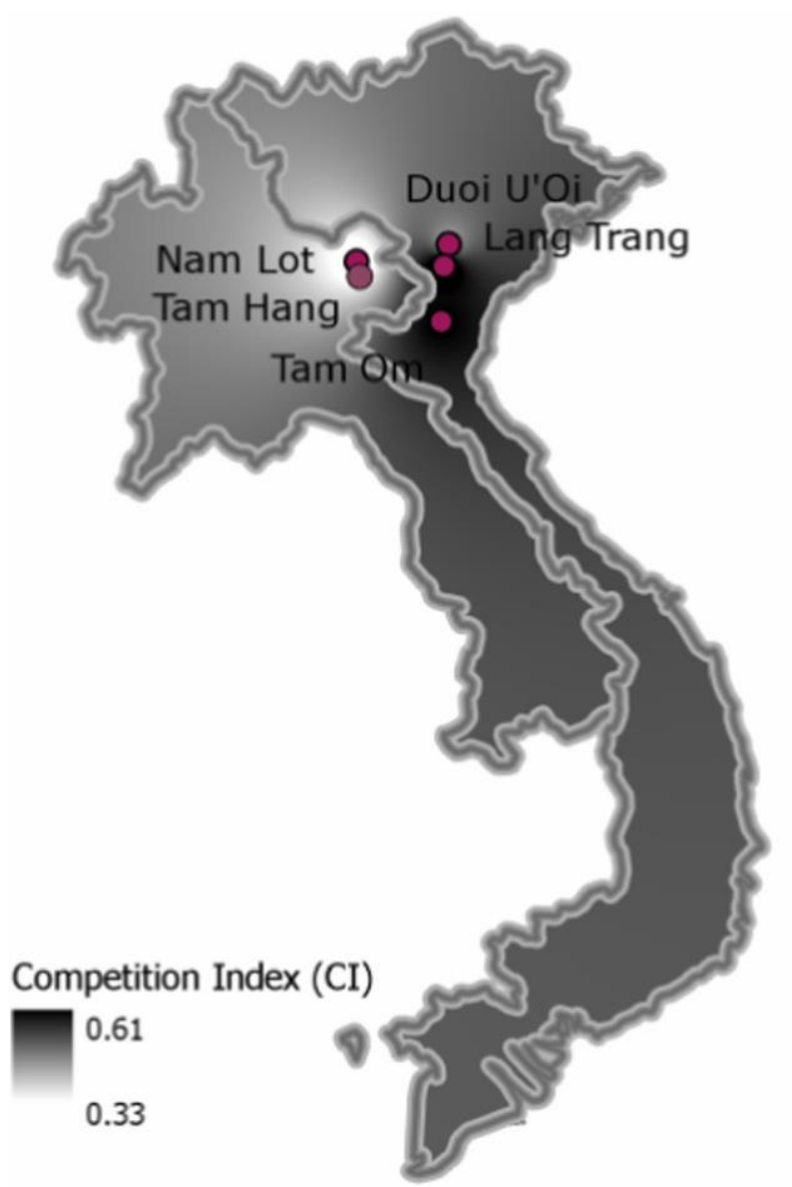

Fig. 6. Competition estimates across Laos and Vietnam at the Last Glacial Maximum based on a sample of 5 study sites. Estimates range from 0.33 to 0.61 , with much of the projected area showing higher $\mathrm{Cl}$ estimates. $\mathrm{Cl}$ data was then used as a layer in Model 3.

Table 5

Table of leave-one-out cross validation (jackknife) testing of variable importance for Model 2 - Temperature, Precipitation, and Terrain. Resulting data reflects the model training gain with estimated contribution and importance of each variable in providing ENM output. In Model 2 terrain slope pulls the model predictions.

\begin{tabular}{lll}
\hline Model 2 variable & Percent contribution & Permutation importance \\
\hline Terrain Slope & 72.9 & 54.3 \\
Temperature & 25.8 & 45.7 \\
Precipitation & 1.3 & 0 \\
\hline
\end{tabular}

Table 6

Maximum $\mathrm{Cl}$ estimates for humans and five predator species across all sites representing maximum competitive potential across mainland Southeast Asia. $\mathrm{x}->\mathrm{y}$ denotes competition species $\mathrm{x}$ feels from species $\mathrm{y}$. $\mathrm{Cl}$ on a scale from 0 to 1 where 1 represents $100 \%$ prey overlap.

\begin{tabular}{lllllll}
\hline Max Cl $(\mathrm{x}->\mathrm{y})$ & Dhole & Golden Cat & Hyena & Leopard & Tiger & Human \\
\hline Dhole & & 0.55 & 0.42 & 0.64 & 0.09 & 0.58 \\
Golden Cat & 1 & & 0 & 0 & 0 & 0.1 \\
Hyena & 0.33 & 0 & 0.66 & 0.55 & 0.6 \\
Leopard & 0.36 & 0 & 1 & & 0.38 & 0.55 \\
Tiger & 0.09 & 0 & 0.44 & 0.25 & & 0.22 \\
Human & 0.5 & 0.11 & 0.6 & 0.66 & 0.33 &
\end{tabular}

Table 7

Cl estimates for carnivores at Duoi U'oi, Lang Trang, and Tam Om, Vietnam as well as Tam Hang and Nam Lot, Laos. $X$ - > y denotes competition species $X$ feels from species $y .{ }^{*}$ denotes hominin presence, but estimated mass and $\mathrm{Cl}$ from literature rather than bony measures.

\begin{tabular}{|c|c|c|c|c|c|}
\hline Lang Trang $(\mathrm{x}->\mathrm{y})$ & Dhole & Golden Cat & Leopard & Tiger & Homo sp. \\
\hline Dhole & & 0.36 & 0.81 & 0.27 & 0.81 \\
\hline Golden cat & 0.36 & & 0.13 & 0 & 0.11 \\
\hline Leopard & 0.5 & 0.13 & & 0.38 & 0.72 \\
\hline Tiger & 0.18 & 0 & 0.25 & & 0.29 \\
\hline Human & 0.63 & 0.11 & 0.61 & 0.43 & \\
\hline $\operatorname{Nam} \operatorname{Lot}(x->y)$ & Dhole & Hyena & Human & & \\
\hline Dhole & & 0.42 & 0.58 & & \\
\hline Hyena & 0.17 & & 0.6 & & \\
\hline Human & 0.42 & 0.6 & & & \\
\hline Tam Hang $(x->y)$ & Dhole & Tiger & Human & & \\
\hline Dhole & & 0.27 & 0.75 & & \\
\hline Tiger & 0.18 & & 0.22 & & \\
\hline Human & 0.58 & 0.33 & & & \\
\hline Tham Om $(x->y)$ & Dhole & Golden Cat & Leopard & Tiger & Homo sp* \\
\hline Dhole & & 0.55 & 0.27 & 0.09 & 0.58 \\
\hline Golden cat & 0.45 & & 0 & 0 & 0.11 \\
\hline Leopard & 0.18 & 0 & & 0.5 & 0.44 \\
\hline Tiger & 0.09 & 0 & 0.5 & & 0.22 \\
\hline Human & 0.42 & 0.11 & 0.56 & 0.33 & \\
\hline Duoi U'Oi $(x->y)$ & Dhole & Leopard & Tiger & Homo sp* & \\
\hline Dhole & & 0.81 & 0.09 & 0.58 & \\
\hline Leopard & 0.45 & & 0 & 0.56 & \\
\hline Tiger & 0.09 & 0 & & 0.22 & \\
\hline Human & 0.42 & 0.33 & 0.33 & & \\
\hline
\end{tabular}

\section{Table 8}

Table of leave-one-out cross validation (jackknife) testing of variable importance for Model 3 - Local scale Temperature, Precipitation, Terrain and $\mathrm{Cl}$. Resulting data reflects the model training gain with estimated contribution and importance of each variable in providing ENM output. In Model 3 temperature pulls the model predictions. Table of jackknife testing of variable importance for Model 3. Resulting data reflects the model training gain with estimated contribution and importance of each variable in providing ENM output. In Model 3 temperature pulls the model predictions.

\begin{tabular}{lll}
\hline Model 3 variable & Percent contribution & Permutation importance \\
\hline Temperature & 89 & 69.9 \\
Precipitation & 11 & 30.1 \\
Terrain slope & 0 & 0 \\
Competition Index & 0 & 0
\end{tabular}


Sumatra, Indonesia; New Guinea Highlands, Papua New Guinea), therefore landform variation data is likely an environmental layer that should be explored in an Australasian ENM test case (Summerhayes et al., 2016). Within the study area slope ranged from 0 to $27^{\circ}$ (Fig. 4), and in ENM model output slope consistently and completely pulled the model in jackknife testing (regularized training gain $0.68 / 0.92$ ), suggesting that this was more influential in this model than either the mean annual temperature or precipitation layers. Model 2 also produced a more nuanced human land preference estimate (Fig. 5 ), which suggests that under these three variables, a southern pathway to Australia would be considered more favorable, but it is still clear that there is a broad range of habitats considered by the model to be "favorable" to human occupation. Contrary to expectations, most hominin land use sites were found on slopes above $15^{\circ}$, this is reflected in the model, which predicts higher sloped regions (particularly the Annamite Mountains in mainland Southeast Asia) to be preferred by humans. This model could benefit by using further iterations with more predictors before making grand claims about modern human dispersal behavior.

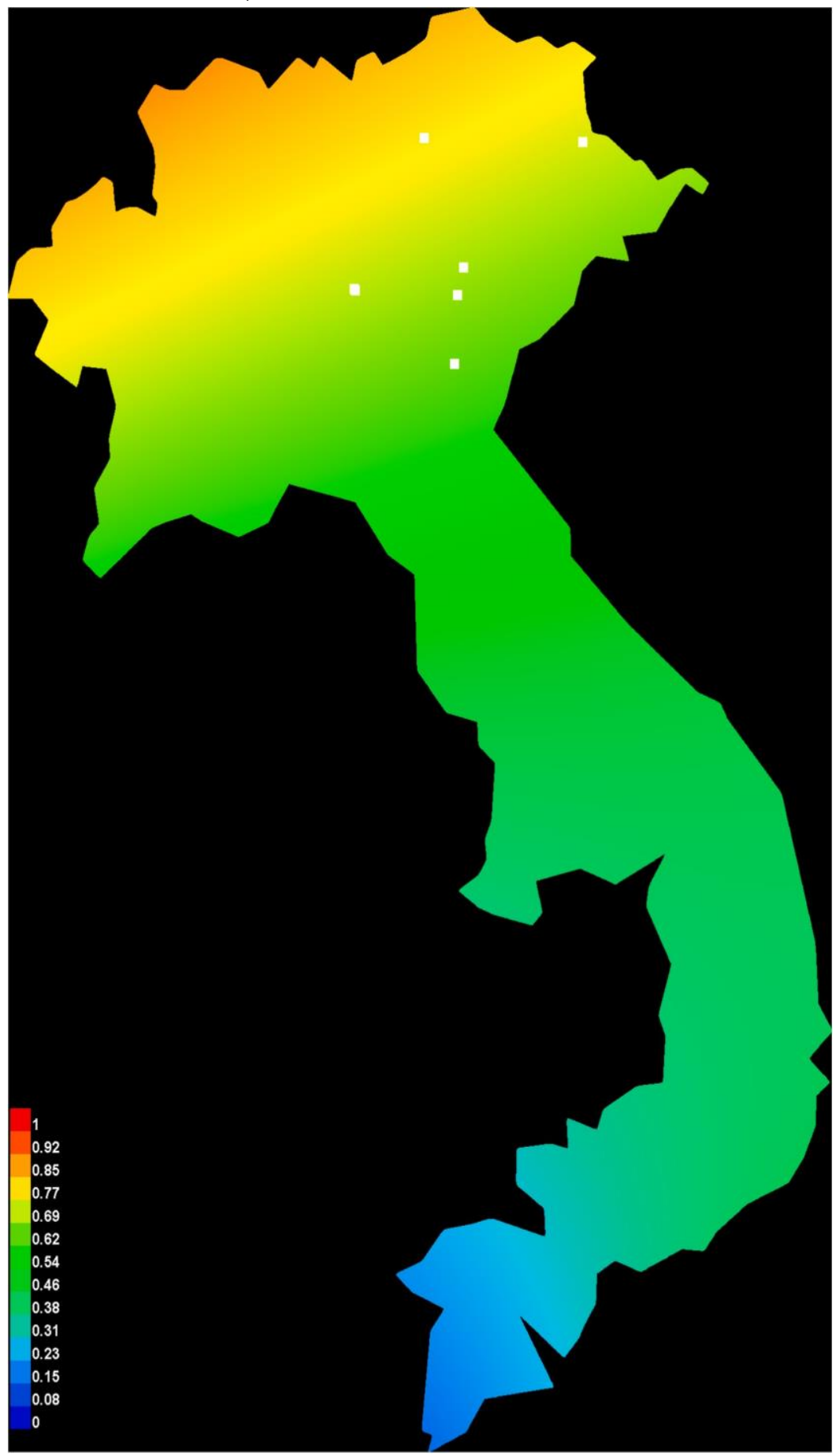

Fig. 7. MaxEnt land favorability output for Laos and Vietnam at the Last Glacial Maximum ( 22-11ka) under Model 3 using temperature, precipitation, terrain slope, and Cl as predictors. Favorability is measured on a scale of $0-1$ along a gradient with warmer colors representing higher favorability than cooler colors. Favorability estimates across the entire region are quite generalized, largely between 0.23 and 0.85 . (For interpretation of the references to color in this figure legend, the reader is referred to the Web version of this article.) 
Slope as a variable that could affect human land preference estimates has not been widely explored in other studies, but it appears to have a greater effect on model predictions and creates an equally accurate ( $A U C=0.924$ ) but more precise estimate in Southeast Asian landscapes. This suggests that more landform data variables (e.g., elevations, sea levels and sea crossings (Kealy et al., 2017, 2018), rainforest locations/vegetation maps) should be explored as predictors that may be valuable in creating more precise large-scale maps of human land preference with ENM. It is also worth noting that while this space did consistently maintain rainforest patches across glacials and interglacials which supported human occupation, it was also a unique mix of multiple biomes (e.g., temperate grassland and montane forest) (Gathorne-Hardy et al., 2002; Boivin et al., 2013), therefore a categorical vegetation type matrix could be of use here.

Model 3 maintained all previous abiotic variables and used $\mathrm{Cl}$ to integrate a biotic variable into an analysis of hindcasted human mobility. The $\mathrm{Cl}$ was used as one biotic variable to obtain a picture of whether competition between humans and these species likely existed, and - if so - did this competitive potential change human land preference estimates when added to solely abiotic ENM models of human land preference. This model was restricted to a localized scale of Laos and Vietnam until more $\mathrm{Cl}$ data can be obtained for additional locations in Australasia so as to not overestimate the importance of this variable on overall land preference. The fit of Model 3 was drastically lower than the preceding iterations ( $A \cup C=0.695$ ) and showed broad favorability estimates comparable with Model 1 (Fig. 7), despite high competition estimates (Tables 6 and 7). While we expected that competition, if high, would reduce favorability (Hoare, 2019), (e.g., humans would move away from these spaces or seek resources elsewhere) this was not supported in the ENM. Despite high competition estimates both across the region and site-specifically (Table 7, Fig. 6), all study sites maintained relatively high overall competitive estimates (Table 6), thereby possibly predicting the variable as unimportant because of ubiquitous high $\mathrm{Cl}$ estimates. On the contrary, it is also possible that competition was not a significant factor in Late Pleistocene land preference in northern Laos and Vietnam. This could also be because of the confounding nature of this type of biotic data. While great care was taken to avoid faunal presence bias in these data, it is possible that competition is one of the "messier" biotic variables. Indeed, it has been suggested that environmental corridors in this region would have likely promoted Pleistocene faunal and human migration and consequent predator-prey interactions (Tougard, 2001; Gathorne-Hardy et al., 2002; Tougard and Montuire, 2006; Louys and Turner, 2012). However, because this is the first such test of its kind, we suggest further examination of this and other biotic variables as potentially important to ENM predictions - particularly in light of the high competitive estimates obtained from the $\mathrm{Cl}$ analysis which, though maximums, provide evidence that at least some interspecific competition was likely occurring. All of these confounding factors may be at play in these data, and only inclusions of more data may allow us to unpack these questions further.

Additionally, contrary to expectations, mean annual temperature rather than slope or $\mathrm{Cl}$ was considered the most important variable by jackknife test of variable importance for Model 3 (Table 8). There are several possible reasons for the relatively poor accuracy and precision of this model. Firstly, while the dataset may be large on an overall scale, moving the analysis to a localized scale may require more fine-grained estimates of temperature and precipitation from local sources rather than from a broad dataset curated for all of Australasia. Secondly, all sites for $\mathrm{Cl}$ are located within the Annamite Mountains and have relatively steep slopes. This could confound the model's accuracy because if slope values are consistently high across the area, it would not be considered an important distinguishing variable for locating human presence because of its lack of variability on this localized scale, as with $\mathrm{Cl}$. Furthermore, the drastic differences in model fits (of the same variables) at broad and narrow scales provides evidence that not all ENM variables, or analyses, are created equal. It is quite possible that broad and narrow focus comparisons require different variables to obtain the best fitting model and most likely picture of human land preference in a uniquely temperate region like Australasia and that data may not be transferrable for broad questions about Australasian human dispersal pathways and local on the ground fossil foot survey predictions.

\section{Conclusions}

This Australasian test case of human paleo-ENM provides insight into the use of these types of methods in temperate spaces, and in understanding human niche construction and landscape preference. Here, we used ENM to test human land preference in Australasia during the Last Glacial Maximum (26.5-19ka), in a region that maintained tropical refugia throughout this period. We contend that using ENMs to predict past human movement in temperate ecosystems requires a re-thinking of how we assign "importance" to environmental variables, and that we must create ENM models cognizant of the unique environmental stressors in a longstanding temperate space.

Our results suggest that researchers cannot and should not treat ENM comparisons in temperate climates identically to other comparisons, as building incorrect assumptions into models results in inaccuracy, regardless of the veracity of the data. The most significant variables in European and Western/Central Asian comparisons are variations in temperature and precipitation, which, though they created accurate large-scale models with high AUC scores, were not good predictors of precise human land preference, resulting in vague maps that do not contribute to questions of human dispersal in this region, or provide detail relevant for fossil foot survey. Slope, our proxy for "terrain ruggedness" contributed to the most accurate and precise ENM model in this temperate test case, suggesting additional landform data may be key to creating ENM models of human land preference with applicable results.

At a localized scale, though temperature was considered by jackknife testing to be the most important predictor in Model 3, the low overall fit of the model ( $A \cup C=0.695$ ) as compared to random chance ( $A \cup C=0.5$ ) suggests that temperature is still a poor predictor in a localized space ( $i$.

e., there are other environmental variables at play that are not included in this model which would provide better fitting models on local scales). Thus, temperate specific analyses at any scale may require the inclusion of other biotic and/or abiotic variables that may hold less predictive power in more extreme environments to obtain more accurate predictions of land preference and dispersal pathways in longstanding temperate spaces.

Though our localized analysis including biotic competition data did not suggest competition was important in the ENM simulation of land preference, the relatively high results of the $\mathrm{Cl}$ analysis both by site and overall suggest this variable may be important in larger scale site comparisons and should not be entirely discounted based on the null results of this test case. At a minimum, following the calls in biology to create more comprehensive ENMs (Gavin et al., 2014; Maguire et al., 2015), some kind of species interaction data should be included in further analysis to reduce our assumptions of how humans interacted with their environment and account for that source of variation in our predictive models. Southeast Asian Pleistocene landscapes were a unique mix of variable niches and biomes that have sparked forty years of debate over the dispersal routes of humans to Australia (Birdsell, 1977). It is in these types of varied environments that spatial and environmental analyses of human behavior can be valuable - potentially providing future evidence that could solve this debate. We suggest that this unique environmental context of Late Pleistocene Southeast Asian landscapes promotes the use of additional "nontraditional" variables to obtain ENM predictions in future iterations that may have the ability to discriminate between a grassland northern route or a more forested southern route. Including additional variables such as greater 
landform data, sea crossings and vegetation type, as well as other predictors such as distance to freshwater and aridity proxies can only create more accurate predictions of human land preference, with potential implications for further fossil discovery.

\section{Data availability}

All abiotic variables included in ENM analysis were retrieved from open source databases including the NOAA paleoclimatology database (ncdc.noaa.gov/data-access/paleoclimatology-data/datasets) (Calvo et al., 2007; Partin et al., 2007, 2015; Crundwell et al., 2008; Saikku et al., 2009; Mohtadi et al., 2010, 2014; Ayliffe et al., 2013; Carolin et al., 2013; Denniston et al., 2013a, 2013b; Gibbons et al., 2014; Ford et al., 2015) and the ESRI ArcGIS Living Atlas (https://livingatlas.arcgis. com/en/). (ESRI Terrain Slope in Degrees). $\mathrm{Cl}$ data were compiled by A. Zachwieja and is stored in the Illinois Data Bank repository at the University of Illinois at Urbana-Champaign (Zachwieja, 2019). ENM layers and validation data were also compiled by $A$. Zachwieja and are stored in the Illinois Databank (Zachwieja, 2020).

\section{Location and accession of archaeological materials}

Fossil faunal data was used to calculate the $\mathrm{Cl}$. Faunal data from Tam Hang and Nam Lot, Laos was accessed during the winter of 2015 and was located at the Lao National Museum. Access permissions were gained from the excavating researchers as well as the Lao National Museum and Lao Ministry of Information, Culture and Tourism. All collaborators have been included here as authors. Faunal data from Duoi U'Oi, Tam Om, and Lang Trang, Vietnam were accessed during the winter of 2015 at the Institute of Archaeology in Hanoi where all access permissions were obtained and assisting researchers were included here as authors.

\section{Declaration of competing interest}

We, the authors of this submission "Understanding Late Pleistocene human land preference using ecological niche models in an Australasian test case" declare that we have no conflicts of interest to report.

\section{Acknowledgements}

This work was fundamentally collaborative and could not have been completed without the generosity of researchers in promoting open climate data, as well as researchers and institutions whose collaboration was integral for competition index data collection. Tremendous thanks to those institutions and persons whose permissions and assistance made data collection possible, specifically at the Lao Ministry of Information, Culture, and Tourism and the Vietnamese Institute of Archaeology. Special thanks to Becky Vandewalle for assistance with GIS structure, data formatting, and guiding me through ArcMap. This work and these questions could not have been possible without the generous data sharing of the many researchers whose climate data made these analyses possible. Funding for this work was provided by: University of Illinois at Urbana-Champaign (UIUC) Anthropology Department, UIUC Graduate College, The Explorer's Club Exploration Fund, and the UIUC Beckman Institute CS/AI Award.

\section{References}

Ayliffe, L.K., Gagan, M.K., Zhao, J.X., Drysdale, R.N., Hellstrom, J.C., Hantoro, W.S., Griffiths, M.L., Scott-Gagan, H., Pierre, E.S., Cowley, J.A., Suwargadi, B.W., 2013. Rapid interhemispheric climate links via the Australasian monsoon during the last deglaciation. Nat. Commun. https://doi.org/10.1038/ncomms3908.

Bacon, A.-M., Demeter, F., Schuster, M., Long, V.T., Thuy, N.K., Antoine, P.-O., Sen, S., Nga, H.H., Huong, N.M., 2004. The Pleistocene Ma U'Oi cave, northern Vietnam: palaeontology, sedimentology and palaeoenvironments. Geobios 37, 305-314. https://doi.org/10.1016/j.geobios.2003.03.010.

Bacon, A.-M., Demeter, F., Tougard, C., Vos, J. de, Sayavongkhamdy, T., Antoine, P.-O., Bouasisengpaseuth, B., Sichanthongtip, P., 2008a. Redecouverte d' 'une faune pl'eistocene dans les remplissages karstiques de Tam Hang au Laos : premiers `resultats. Comptes Rendus Palevol 7, 277-288. https://doi.org/10.1016/j. crpv.2008.03.009.

Bacon, A.-M., Duringer, P., Antoine, P.-O., Demeter, F., Shackelford, L., Sayavongkhamdy, T., Sichanthongtip, P., Khamdalavong, P., Nokhamaomphu, S., Sysuphanh, V., PatoleEdoumba, E., Chabaux, F., Pelt, E., 2011. The Middle Pleistocene mammalian fauna from Tam Hang karstic deposit, northern Laos: New data and evolutionary hypothesis. Quat. Int. 245, 315-332. https://doi.org/ 10.1016/j.quaint.2010.11.024.

Bacon, A.-M., Westaway, K., Antoine, P.-O., Duringer, P., Blin, A., Demeter, F., Ponche, J.-L., Zhao, J.-X., Barnes, L.M., Sayavonkhamdy, T., Thuy, N.T.K., Long, V. T., Patole-Edoumba, E., Shackelford, L., 2015. Late Pleistocene mammalian assemblages of Southeast Asia: New dating, mortality profiles and evolution of the predator-prey relationships in an environmental context. Palaeogeogr.

Palaeoclimatol. Palaeoecol. 422, 101-127. https://doi.org/10.1016/j. palaeo.2015.01.011.

Bacon, A.M., Demeter, F., Duringer, P., Rousse, S., Dodo, Y., Matsumura, H., The Long, V., Kim Thuy, N., Huong, N.T.M., Anezaki, T., 2006. Records of murine rodents (mammalia, rodentia) in the pleistocene localities of tan vinh and ma U'oi (northern Vietnam) and their implications to past distribution. Ann. Palaontol. 92, 367-383. https://doi.org/10.1016/j.annpal.2006.03.019.

Bacon, A.M., Demeter, F., Duringer, P., Helm, C., Bano, M., Vu The, Long, Kim Thuy, N. T., Antoine, P.O., Thi Mai, B., Huong, N.T.M., Dodo, Y., Chabaux, F., Rihs, S., 2008b. The Late Pleistocene Duoi U'Oi cave in northern Vietnam: palaeontology, sedimentology, taphonomy and palaeoenvironments. Quat. Sci. Rev. 27, 1627-1654. https://doi.org/10.1016/j.quascirev.2008.04.017.

Bacon, A.M., Bourgon, N., Dufour, E., Zanolli, C., Duringer, P., Ponche, J.L., Antoine, P. O., Shackelford, L., Huong, N.T.M., Sayavonkhamdy, T., Patole-Edoumba, E., Demeter, F., 2018a. Nam Lot (MIS 5) and Duoi U'oi (MIS 4) Southeast Asian sites revisited: zooarchaeological and isotopic evidences. Palaeogeogr. Palaeoclimatol. Palaeoecol. 1-13. https://doi.org/10.1016/j.palaeo.2018.03.034.

Bacon, A.M., Duringer, P., Westaway, K., Joannes-Boyau, R., Zhao, J. xin, Bourgon, N., Dufour, E., Pheng, S., Tep, S., Ponche, J.L., Barnes, L., Blin, A., Patole-Edoumba, E., Demeter, F., 2018b. Testing the savannah corridor hypothesis during MIS2: the Boh Dambang hyena site in southern Cambodia. Quat. Int. 464, 417-439. https://doi. org/10.1016/j.quaint.2017.10.047.

Bae, C.J., Li, F., Cheng, L., Wang, W., Hong, H., 2018. Hominin distribution and density patterns in Pleistocene China: climatic influences. Palaeogeogr. Palaeoclimatol. Palaeoecol. 512, 118-131. https://doi.org/10.1016/j.palaeo.2018.03.015.

Barton, C.M., Riel-Salvatore, J., Anderies, J.M., Popescu, G., 2011. Modeling human ecodynamics and biocultural interactions in the late pleistocene of western eurasia. Hum. Ecol. 39, 705-725. https://doi.org/10.1007/s10745-011-9433-8.

Beeton, T.A., Glantz, M.M., Trainer, A.K., Temirbekov, S.S., Reich, R.M., 2014. The fundamental hominin niche in late Pleistocene Central Asia: a preliminary refugium model. J. Biogeogr. 41, 95-110. https://doi.org/10.1111/jbi.12183.

Bible, R.C., 2016. An Analysis of Late Pleistocene Hominin Population Dynamics in Europe Using Ecological Niche Modeling Methods. Texas A\&M University.

Bible, R.C., Peterson, A.T., 2018. Compatible ecological niche signals between biological and archaeological datasets for late-surviving Neandertals. Am. J. Phys. Anthropol. 968-974. https://doi.org/10.1002/ajpa.23482.

Bigg, G.R., Cunningham, C.W., Ottersen, G., Pogson, G.H., Wadley, M.R., Williamson, P., 2008. Ice-age survival of Atlantic cod: agreement between palaeoecology models and genetics. Proc. Biol. Sci. 275 https://doi.org/10.1098/rspb.2007.1153, 163- U13.

Bird, M.I., Taylor, D., Hunt, C., 2005. Palaeoenvironments of insular southeast Asia during the last glacial period: a savanna corridor in Sundaland? Quat. Sci. Rev. 24, 2228-2242. https://doi.org/10.1016/j.quascirev.2005.04.004.

Birdsell, J., 1977. The recalibration of a paradigm for the first peopling of greater Australia. Sunda and Sahul: Prehistoric Studies in Southeast Asia, Melanesia and Australia. Cambridge University Press.

Block, S., Saltre, F., Rodriguez-Rey, M., Fordham, D.A., Unkel, I., Bradshaw, C.J.A., 2016. Where to dig for fossils: combining climate-envelope, taphonomy, and discovery models. PloS One 11, 1-17. https://doi.org/10.4227/05/564E6209C4FE8.

Boivin, N., Fuller, D.Q., Dennell, R., Allaby, R., Petraglia, M.D., 2013. Human dispersal across diverse environments of Asia during the upper pleistocene. Quat. Int. 300, 32-47. https://doi.org/10.1016/j.quaint.2013.01.008.

Bowdler, S., 2010. The empty coast: conditions for human occupation in southeast Australia. In: Altered Ecologies: Fire, Climate and Human Influence on Terrestrial Landscapes.

Brantingham, P.J., 1998. Hominid-carnivore coevolution and invasion of the predatory guild. J. Anthropol. Archaeol. 17, 327-353.

Cai, B., Pumijumnong, N., Tan, M., Muangsong, C., Kong, X., Jiang, X., Nan, S., 2010. Effects of intraseasonal variation of summer monsoon rainfall on stable isotope and growth rate of a stalagmite from northwestern Thailand. Journal of Geophysical Research Atmospheres 115, 1-10. https://doi.org/10.1029/2009JD013378.

Caley, T., Roche, D.M., Waelbroeck, C., Michel, E., 2014. Oxygen stable isotopes during the Last Glacial Maximum climate: perspectives from data-model (iLOVECLIM) comparison. Clim. Past 10, 1939-1955. https://doi.org/10.5194/cp-10-1939-2014.

Calvo, E., Pelejero, C., Deckker, P. De, Logan, G.A., 2007. Antarctic deglacial pattern in a $30 \mathrm{kyr}$ record of sea surface temperature offshore South Australia. Geophys. Res. Lett. https://doi.org/10.1029/2007GL029937.

Cannon, C.H., Morley, R.J., Bush, A.B.G., 2009. The Current Refugial Rainforests of Sundaland Are Unrepresentative of Their Biogeographic Past and Highly Vulnerable to Disturbance.

Caro, T.M., Stoner, C.J., 2003. The potential for interspecific competition among African carnivores. Biol. Conserv. 110, 67-75. https://doi.org/10.1016/S0006-3207(02) 00177-5. 
Carolin, S.A., Cobb, K.M., Adkins, J.F., Clark, B., Conroy, J.L., Lejau, S., Malang, J., Tuen, A.A., 2013. Varied response of western Pacific hydrology to climate forcings over the last glacial period. Science. https://doi.org/10.1126/science.1233797.

Churchill, S.E., 2014. Thin on the ground: neandertal biology, archeology and ecology, thin on the ground: neandertal biology, archeology and ecology. https://doi.org/ 10.1002/9781118590836.

Ciochon, R.L., 2010. Divorcing hominins from the stegodon-ailuropoda fauna: New views on the antiquity of hominins in Asia. In: Fleagle, J.G., Shea, J.J., Grine, F.E., Baden, A.L., Leakey, R.E. (Eds.), Out of Africa 1: the First Hominin Colonization of Eurasia. Springer, pp. 153-154. https://doi.org/10.1007/978-90-481-9036-2.

Clark, P.U., Dyke, A.S., Shakun, J.D., Carlson, A.E., Clark, J., Wohlfarth, B., Mitrovica, J. X Hostetler, S.W., McCabe, A.M., 2009. The last glacial maximum. Science 325, 710-714. https://doi.org/10.1126/science.1172873

Cook, C.G., Jones, R.T., 2012. Palaeoclimate dynamics in continental Southeast Asia over the last 30,000Calyrs BP. Palaeogeogr. Palaeoclimatol. Palaeoecol. 339-341, 1-11. https://doi.org/10.1016/j.palaeo.2012.03.025.

Costa, G.C., Nogueira, C., Machado, R.B., Colli, G.R., 2010. Sampling bias and the use of ecological niche modeling in conservation planning: a field evaluation in a biodiversity hotspot. Biodivers. Conserv. 19, 883-899. https://doi.org/10.1007/ s10531-009-9746-8.

Crundwell, M., Scott, G., Naish, T., Carter, L., 2008. Glacial-interglacial ocean climate variability from planktonic foraminifera during the Mid-Pleistocene transition in the temperate Southwest Pacific, ODP Site 1123. Palaeogeogr. Palaeoclimatol. Palaeoecol. https://doi.org/10.1016/j.palaeo.2007.08.023.

Cuong, N.L., 1992. A reconsideration of the chronology of hominid fossils in Vietnam. In: The Evolution of Dispersion of Hominids in Asia, pp. 321-325.

Davis, E.B., Mcguire, J.L., Orcutt, J.D., 2014. Ecological niche models of mammalian glacial refugia show consistent bias. Ecography 37, 1133-1138. https://doi.org/ 10.1111/ecog.01294.

Demeter, F., Bacon, A.-M., Nguyen, T.K.T., Long, V.T., Matsumura, H., Nga, H.H., Schuster, M., Nguyen, M.H., Coppens, Y., 2004. An archaic Homo molar from northern Vietnam. Curr. Anthropol. 45, 535-541.

Demeter, F., Shackelford, L., Westaway, K., Barnes, L., Duringer, P., Ponche, J.-L., Dumoncel, J., Sen' egas, F., Sayavongkhamdy, T., Zhao, J.-X., Sichanthongtip, P., Patole-Edoumba, E., Dunn, T., Zachwieja, A., Coppens, Y., Willerslev, E., Bacon, A.- M., 2017. Early modern humans from Tam pa ling, Laos: fossil review and 'perspectives. Curr. Anthropol. 58 https://doi.org/10.1086/694192. S000-S000.

Dennell, R.W., Martinon-Torres, M., Bermúdez de Castro, J.M., 2011. Hominin 'variability, climatic instability and population demography in Middle Pleistocene Europe. Quat. Sci. Rev. 30, 1511-1524. https://doi.org/10.1016/j. quascirev.2009.11.027.

Denniston, R.F., Asmerom, Y., Lachniet, M., Polyak, V.J., Hope, P., An, N., Rodzinyak, K., Humphreys, W.F., 2013a. A Last Glacial Maximum through middle Holocene stalagmite record of coastal Western Australia climate. Quat. Sci. Rev. https://doi. org/10.1016/j.quascirev.2013.07.002.

Denniston, R.F., Wyrwoll, K.H., Asmerom, Y., Polyak, V.J., Humphreys, W.F., Cugley, J., Woods, D., LaPointe, Z., Peota, J., Greaves, E., 2013b. North Atlantic forcing of millennial-scale IndoAustralian monsoon dynamics during the Last Glacial period. Quat. Sci. Rev. https://doi.org/10.1016/j.quascirev.2013.04.012

Dunbar, R.I.M., Bever, J., 1998. Neocortex size predicts group size in carnivores and some insectivores. Ethology 104, 695-708.

Duringer, P., Bacon, A.-M., Sayavongkhamdy, T., Nguyen, T.K.T., 2012. Karst development, breccias history, and mammalian assemblages in Southeast Asia: a brief review. Comptes Rendus Palevol 11, 133-157. https://doi.org/10.1016/j. crpv.2011.07.003.

Earle, M., 1987. A flexible body mass in social carnivores. Am. Nat. 129, 755-760.

Endt, D.W. Von, Ortner, D.J., 1984. Experimental effects of bone size and temperature on bone diagenesis. J. Archaeol. Sci. https://doi.org/10.1016/0305-4403(84)90005-0.

Fedriani, J.M., Fuller, T.K., Sauvajot, R.M., York, E.C., 2000. Competition and intraguild predation among three sympatric carnivores. Oecologia. https://doi.org/10.1007/ s004420000448.

Field, J.S., Petraglia, M.D., Lahr, M.M., 2007. The southern dispersal hypothesis and the South Asian archaeological record: examination of dispersal routes through GIS analysis. J. Anthropol. Archaeol. 26, 88-108. https://doi.org/10.1016/j. jaa.2006.06.001.

Finarelli, J. a, Flynn, J.J., 2006. Ancestral state reconstruction of body size in the Caniformia (Carnivora, Mammalia): the effects of incorporating data from the fossil record. Syst. Biol. 55, 301-313. https://doi.org/10.1080/10635150500541698.

Ford, H.L., Ravelo, A.C., Dekens, P.S., Lariviere, J.P., Wara, M.W., 2015. The evolution of the equatorial thermocline and the early Pliocene El Padre mean state. Geophys. Res. Lett. https://doi.org/10.1002/2015GL064215.

Furtado, J.C. Lorenzo, E. Di, Cobb, K.M., Bracco, A. 2009. Paleoclimate reconstructions of tropical sea surface temperatures from precipitation proxies: methods, uncertainties, and nonstationarity. J. Clim. 22, 1104-1123. https://doi.org/ 10.1175/2008JCLI2415.1.

Gathorne-Hardy, F.J., Syaukani, Davies, R.G., Eggleton, P., Jones, D.T., 2002. Quaternary rainforest refugia in south-east Asia: using termites (Isoptera) as indicators. Biol. J. Linn. Soc. 75, 453-466. https://doi.org/10.1046/j.1095-8312.2002.00031.x.

Gavin, D.G., Fitzpatrick, M.C., Gugger, P.F., Heath, K.D., Rodríguez-Sanchez, F., ' Dobrowski, S.Z., Hampe, A., Hu, F.S., Ashcroft, M.B., Bartlein, P.J., Blois, J.L., Carstens, B.C., Davis, E.B., Lafontaine, G. de, Edwards, M.E., Fernandez, M.,

Henne, P.D., Herring, E.M., Holden, Z.A., Kong, W-S., Liu, J., Magri, D., Matzke, N.J., Mcglone, M.S., Saltr'e, F., Stigall, A.L., Tsai, Y.H.E., Williams, J.W., 2014. Climate refugia: joint inference from fossil records, species distribution models and phylogeography. New Phytol. 204, 37-54. https://doi.org/10.1111/nph.12929.
Gibbons, F.T., Oppo, D.W., Mohtadi, M., Rosenthal, Y., Cheng, J., Liu, Z., Linsley, B.K., 2014. Deglacial $\delta 180$ and hydrologic variability in the tropical Pacific and Indian Oceans. Earth Planet Sci. Lett. https://doi.org/10.1016/j.epsl.2013.11.032.

Glantz, M., Arsdale, A. Van, Temirbekov, S., Beeton, T., 2018. How to survive the glacial apocalypse: hominin mobility strategies in late Pleistocene Central Asia. Quat. Int. 466, 82-92. https://doi.org/10.1016/j.quaint.2016.06.037.

Guisan, A., Thuiller, W., 2005. Predicting species distribution: offering more than simple habitat models. Ecol. Lett. 8, 993-1009. https://doi.org/10.1111/j.1461- 0248.2005.00792.x.

Hanson, D.B., Buikstra, J.E., 1987. Histomorphological alteration in buried human bone from the lower Illinois Valley: implications for palaeodietary research. J. Archaeol. Sci. https://doi.org/10.1016/0305-4403(87)90038-0.

Harihar, A., Pandav, B., Goyal, S.P., 2011. Responses of leopard Panthera pardus to the recovery of a tiger Panthera tigris population. J. Appl. Ecol. 48, 806-814. https:// doi.org/10.1111/j.1365-2664.2011.01981.x.

Heaney, L., 1991. A synopsis of climatic and vegetational change in Southeast Asia. Climatic Change 19, 53-61. https://doi.org/10.1007/BF00142213.

Heaney, L.R., 1986. Biogeography of mammals in SE Asia: estimates of rates of colonization, extinction and speciation. Biol. J. Linn. Soc. 28, 127-165. https://doi. org/10.1111/j.10958312.1986.tb01752.x.

Hemmer, H., 2004. Notes on the ecological role of European cats (Mammalia: felidae) of the last two million years. In: Zona Arqueologica 4. Miscelanea En Homenaje a Emiliano Aguirre, vol. II, pp. 214-232. Paleontologia.

Hertler, C., Volmer, R., 2008. Assessing prey competition in fossil carnivore communities - a scenario for prey competition and its evolutionary consequences for tigers in Pleistocene Java. Palaeogeogr. Palaeoclimatol. Palaeoecol. 257, 67-80. https://doi. org/10.1016/j.palaeo.2007.09.004.

Higgins, R.W., 2014. The effects of terrain on long bone robusticity and cross-sectional shape in lower limb bones of bovids, neandertals and upper paleolithic modern humans. In: Reconstructing Mobility : Environmental , Behavioral and Morphological Determinants, pp. 227-252. https://doi.org/10.1007/978-1-4899-7460-0.

Higgins, R.W., Ruff, C.B., 2011. The effects of distal limb segment shortening on locomotor efficiency in sloped terrain: implications for Neandertal locomotor behavior. Am. J. Phys. Anthropol. 146, 336-345.

Hoare, S., 2019. The possible role of predator - prey dynamics as an influence on early hominin use of burned landscapes. Evol. Anthropol. 1-8. https://doi.org/10.1002/ evan.21807.

Hughes, J.K., Haywood, A., Mithen, S.J., Sellwood, B.W., Valdes, P.J., 2007. Investigating early hominin dispersal patterns: developing a framework for climate data integration. J. Hum. Evol. 53, 465-474. https://doi.org/10.1016/j. jhevol.2006.12.011.

Jennings, R.P., Singarayer, J., Stone, E.J., Krebs-Kanzow, U., Khon, V., Nisancioglu, K.H., Pfeiffer M., Zhang, X., Parker, A., Parton, A., Groucutt, H.S., White, T.S., Drake, N. A., Petraglia, M.D., 2015. The greening of Arabia: multiple opportunities for human occupation of the Arabian Peninsula during the Late Pleistocene inferred from an ensemble of climate model simulations. Quat. Int. 382, 181-199. https://doi.org/ 10.1016/j.quaint.2015.01.006.

Kealy, S., Louys, J., O'Connor, S., 2017. Reconstructing palaeogeography and inter- island visibility in the wallacean archipelago during the likely period of sahul colonization, 6545000 Years ago. Archaeol. Prospect. https://doi.org/10.1002/ arp.1570.

Kealy, S., Louys, J., O'Connor, S., 2018. Least-cost pathway models indicate northern human dispersal from Sunda to Sahul. J. Hum. Evol. 125, 59-70. https://doi.org/ 10.1016/j.jhevol.2018.10.003

Kershaw, A.P., Penny, D., van der Kaars, S., Anshari, G., Thamotherampillai, T., 2001. Vegetation and Climate in Lowland Southeast Asia at the Last Glacial Maximum, Faunal and Floral Migrations and Evolution in Se Asia-Australasia. Balkema, Lisse.

Larick, R., Ciochon, R.L., 2015. Early hominin biogeography in island Southeast Asia. Evol. Anthropol. 24, 185-213. https://doi.org/10.1002/evan.21460.

Lewis, M.E., 2017. Carnivore guilds and the impact of hominin dispersals. In: Boivin, N., Crassard, R., Petraglia, M. (Eds.), Human Dispersal and Species Movement: from Prehistory to Present. Cambridge University Press, Cambridge, MA, pp. 29-61.

Linnell, J.D.C., Strand, O., 2000. Interference interactions,co-existence and conservation of mammalian carnivores. Biodiversity Research 6, 169-176. https://doi.org/ 10.1046/j.14724642.2000.00069.x.

Louys, J., 2014. The large terrestrial carnivore guild in Quaternary Southeast Asia. Quat. Sci. Rev. 96, 86-97. https://doi.org/10.1016/j.quascirev.2013.06.014.

Louys, J., Turner, A., 2012. Environment, preferred habitats and potential refugia for Pleistocene Homo in Southeast Asia. Comptes Rendus Palevol 11, 203-211. https:// doi.org/10.1016/j.crpv.2011.03.003.

Lozier, J.D., Aniello, P., Hickerson, M.J., 2009. Predicting the distribution of Sasquatch in western North America: anything goes with ecological niche modelling. J. Biogeogr. https://doi.org/10.1111/j.1365-2699.2009.02152.x.

Lyman, R.L., 2014. Vertebrate taphonomy. Vertebrate Taphonomy. https://doi.org/ 10.1017/СВO9781139878302

Maguire, K.C., Nieto-Lugilde, D., Fitzpatrick, M.C., Williams, J.W., Blois, J.L., 2015. Modeling species and community responses to past, present, and future episodes of climatic and ecological change. Annu. Rev. Ecol. Evol. Syst. 46, 343-368. https:// doi.org/10.1146/annurev-ecolsys-112414-054441.

Marchi, D., 2008. Relationships between lower limb cross-sectional geometry and mobility: the case of a Neolithic sample from Italy. Am. J. Phys. Anthropol. 137, 188-200. https://doi.org/10.1002/ajpa.20855.

Martínez-Meyer, E., Peterson, A.T., 2006. Conservatism of ecological niche characteristics in North American plant species over the Pleistocene-to-Recent transition. J. Biogeogr. 33 https://doi.org/10.1111/j.1365-2699.2006.01482 33_10. x. 
Marwick, B., 2009. Biogeography of Middle Pleistocene hominins in mainland Southeast Asia: a review of current evidence. Quat. Int. 202, 51-58. https://doi.org/10.1016/j. quaint.2008.01.012.

McColl, H., Racimo, F., Vinner, L., Demeter, F., Gakuhari, T., Moreno-mayar, J.V., Driem, G. Van, Wilken, U.G., Seguin-orlando, A., De, C., Castro, F., 2018. The prehistoric peopling of Southeast Asia. Science 361, 88-92.

Meijaard, E., 2003. Mammals of south-east Asian islands and their late Pleistocene environments. J. Biogeogr. 30, 1245-1257. https://doi.org/10.1046/j.13652699.2003.00890.x

Mohtadi, M., Steinke, S., Lückge, A., Groeneveld, J., Hathorne, E.C., 2010. Glacial to Holocene surface hydrography of the tropical eastern Indian Ocean. Earth Planet Sci. Lett. https://doi.org/10.1016/j.epsl.2010.01.024.

Mohtadi, M., Prange, M., Oppo, D.W., Pol-Holz, R. De, Merkel, U., Zhang, X., Steinke, S., Lückge, A., 2014. North Atlantic forcing of tropical Indian Ocean climate. Nature. https://doi.org/10.1038/nature13196.

Morgan, C., 2009. Climate change, uncertainty and prehistoric hunter-gatherer mobility. J. Anthropol. Archaeol. 28, 382-396. https://doi.org/10.1016/j.jaa.2009.07.004.

Mudar, K., Anderson, D.D., 2007. New evidence for Southeast asian pleistocene foraging economies: faunal remains from the early levels of Lang rongrien rockshelter, krabi, Thailand. Asian Perspect. 46, 298-334. https://doi.org/10.1353/asi.2007.0013.

Norman, K., Inglis, J., Clarkson, C., Faith, J.T., Shulmeister, J., Harris, D., 2018. An early colonisation pathway into northwest Australia 70-60,000 years ago. Quat. Sci. Rev. 180, 229-239. https://doi.org/10.1016/j.quascirev.2017.11.023.

Odden, M., Wegge, P., Fredriksen, T., 2010. Do tigers displace leopards? If so, why? Ecol. Res. 25, 875-881. https://doi.org/10.1007/s11284-010-0723-1.

Olsen, J.W., Ciochon, R.L., 1990. A review of evidence for postulated Middle Pleistocene occupations in Viet Nam. J. Hum. Evol. 19, 761-788. https://doi.org/10.1016/ 00472484(90)90020-C.

Palmer, T.M., Stanton, M.L., Young, T.P., 2003. Competition and coexistence: exploring mechanisms that restrict and maintain diversity within mutualist guilds. Am. Nat. 162, S63-S79. https://doi.org/10.1086/378682.

Partin, J.W., Cobb, K.M., Adkins, J.F., Clark, B., Fernandez, D.P., 2007. Millennial-scale trends in west Pacific warm pool hydrology since the Last Glacial Maximum. Nature. https://doi.org/10.1038/nature06164

Partin, J.W., Quinn, T.M., Shen, C.C., Okumura, Y., Cardenas, M.B., Siringan, F.P., Banner, J.L., Lin, K., Hu, H.M., Taylor, F.W., 2015. Gradual onset and recovery of the Younger Dryas abrupt climate event in the tropics. Nat. Commun. https://doi.org/ 10.1038/ncomms9061.

Petraglia, M.D., Breeze, P.S., Groucutt, H.S., 2019. Blue arabia, green arabia: examining human colonisation and dispersal models. Geological Setting, Palaeoenvironment and Archaeology of the Red Sea. Springer International Publishing, pp. 675-683. https://doi.org/10.1007/978-3-319-99408-6.

Phillips, S.J., Dudík, M., Schapire, R.E., 2004. A maximum entropy approach to species distribution modeling. https://doi.org/10.1145/1015330.1015412, 21st International Conference on Machine Learning, Banff, Canada 655-662.

Phillips, S.J., Dudik, M., Schapire, R.E., 2017. Maxent Software for Modeling Species Niches and Distributions.

Preston, K.L., Rotenberry, J.T., Redak, R.A., Allen, M.F., 2008. Habitat shifts of endangered species under altered climate conditions: importance of biotic interactions. Global Change Biol. https://doi.org/10.1111/j.1365- 2486.2008.01671.x.

Rizal, Y., Westaway, K.E., Zaim, Y., van den Bergh, G.D., Bettis III, E.A., Morwood, M.J., Huffman, O.F., Grün, R., Joannes-Boyau, R., Bailey, R.M., Westaway, M.C., Kurniawan, I., Moore, M.W., Storey, M., Aziz, F., Zhao, J., xin, Aswan, Sipola, M.E., Larick, R., Zonneveld, J.P., Scott, R., Putt, S., Ciochon, R.L., 2019. Last appearance of Homo erectus at Ngandong, Java, 117,000-108,000 years ago. Nature. https://doi. org/10.1038/s41586019-1863-2.

Roberts, P., Petraglia, M., 2015. Pleistocene rainforests: barriers or attractive environments for early human foragers? World Archaeol. 1-22. https://doi.org/ 10.1080/00438243.2015.1073119.

Rodríguez, J., Mateos, A., Hertler, C., Palombo, M.R., Universit, S., 2015. Modelling human presence and environmental dynamics during the Mid-Pleistocene Revolution: New approaches and tools. Quat. Int. 393, 5-9. https://doi.org/ 10.1016/j.quaint.2015.06.003.

Russell, J., Bijaksana, S, 2012. The Towuti drilling project: paleoenvironments, biological evolution, and geomicrobiology of a tropical pacific lake. Sci. Drill. 68-71. https://doi.org/10.2204/iodp.sd.14.11.2012.

Saikku, R., Stott, L., Thunell, R., 2009. A bi-polar signal recorded in the western tropical Pacific: northern and Southern Hemisphere climate records from the Pacific warm pool during the last Ice Age. Quat. Sci. Rev. https://doi.org/10.1016/j. quascirev.2009.05.007.

Shackelford, L., Demeter, F., 2012. The place of Tam Hang in Southeast asian human evolution. Comptes Rendus Palevol 11, 97-115. https://doi.org/10.1016/j. crpv.2011.07.002.

Shackelford, L., Demeter, F., Westaway, K., Duringer, P., Ponche, J.-L.L., Sayavongkhamdy, T Zhao, J.-X.X., Barnes, L., Boyon, M., Sichanthongtip, P., S'en'egas, F., Patole-Edoumba, E., Coppens, Y., Dumoncel, J., Bacon, A.-M.M., 2018

Additional evidence for early modern human morphological diversity in Southeast Asia at Tam Pa Ling, Laos. Quat. Int. 466, 93-106. https://doi.org/10.1016/j. quaint.2016.12.002.

Shi, M.M., Michalski, S.G., Welk, E., Chen, X.Y., Durka, W., 2014. Phylogeography of a widespread Asian subtropical tree: Genetic east-west differentiation and climate envelope modelling suggest multiple glacial refugia. J. Biogeogr. https://doi.org/ 10.1111/jbi.12322.

Sillero, N., 2011. What does ecological modelling model? A proposed classification of ecological niche models based on their underlying methods. Ecol. Model. 222, 1343-1346. https://doi.org/10.1016/j.ecolmodel.2011.01.018.
Steinmetz, R., Seuaturien, N., Chutipong, W., 2013. Tigers, leopards, and dholes in a half- empty forest: assessing species interactions in a guild of threatened carnivores. Biol. Conserv. 163 , 68-78. https://doi.org/10.1016/j.biocon.2012.12.016

Stewart, J.R., Stringer, C.B., 2012. Human evolution out of Africa: the role of refugia and climate change. Science 335, 1317-1321. https://doi.org/10.1126/ science.1215627.

Summerhayes, G.R., Field, J.H., Shaw, B., Gaffney, D., 2016. The archaeology of forest exploitation and change in the tropics during the Pleistocene: the case of Northern Sahul (Pleistocene New Guinea). Quat. Int. https://doi.org/10.1016/j. quaint.2016.04.023.

Svenning, J.C., Fløjgaard, C., Marske, K.A., Nogues-Bravo, D., Normand, S., 2011. ' Applications of species distribution modeling to paleobiology. Quat. Sci. Rev. 30, 2930-2947. https://doi.org/10.1016/j.quascirev.2011.06.012.

Tarkesh, M., Jetschke, G., 2012. Comparison of six correlative models in predictive vegetation mapping on a local scale. Environ. Ecol. Stat. 19, 437-457. https://doi. org/10.1007/s10651-012-0194-3

Tougard, C., 2001. Biogeography and migration routes of large mammal faunas in South- East Asia during the late middle Pleistocene: focus on the fossil and extant faunas from Thailand. Palaeogeogr. Palaeoclimatol. Palaeoecol. 168, 337-358. https://doi. org/10.1016/\$00310182(00)00243-1.

Tougard, C., Montuire, S., 2006. Pleistocene paleoenvironmental reconstructions and mammalian evolution in South-East Asia: focus on fossil faunas from Thailand. Quat. Sci. Rev. 25, 126-141. https://doi.org/10.1016/j.quascirev.2005.04.010.

Townsend Peterson, A., Papes, M., Eaton, M., Peterson, A.T., Papes, M., Eaton, M., Townsend Peterson, A., 2007. Transferability and model evaluation in ecological niche modeling: a comparison of GARP and Maxent. Ecography 30, 550-560. https://doi.org/10.1111/j.0906-7590.2007.05102.x.

Treves, A., Naughton-Treves, L., 1999. Risk and opportunity for humans coexisitng with large carnivores. J. Hum. Evol. 36, 275-282. https://doi.org/10.1006/ jhev.1998.0268.

Treves, A., Palmqvist, P., 2007. Reconstructing hominin interactions with mammalian carnivores (6.0-1.8 ma), primate anti-predator strategies. https://doi.org/10.1007/ 978-0387-34810-0_17.

Valkenburgh, B. Van, 1990. Skeletal and dental predictors of body mass in carnivores. Body Size in Mammalian Paleobiology: Estimation and Biological Implications, pp. 181-205.

Varela, S., Lobo, J.M., Rodríguez, J., Batra, P., 2010. Were the Late Pleistocene climatic changes responsible for the disappearance of the European spotted hyena populations? Hindcasting a species geographic distribution across time. Quat. Sci. Rev. 29, 2027-2035. https://doi.org/10.1016/j.quascirev.2010.04.017.

Varela, S., Lobo, J.M., Hortal, J., 2011. Using species distribution models in paleobiogeography: a matter of data, predictors and concepts. Palaeogeogr.

Palaeoclimatol. Palaeoecol. https://doi.org/10.1016/j.palaeo.2011.07.021.

Verstappen, H.T.H., 1997. The effect of climatic change on southeast Asian geomorphology. J. Quat. Sci. 12, 413-418. https://doi.org/10.1002/(SICl)10991417(199709/10)12:5<413::AID-JOS324>3.3.CO;2-G.

Volmer, R., Hertler, C., 2016. The effect of competition on shared food resources in carnivore guilds. Quat. Int. 413, 32-43. https://doi.org/10.1016/j. quaint.2015.11.054.

Walker, C.C.S., Churchill, S.S.E., 2011. Territory size in Canis lupus: implications for Neandertal mobility. AMERICAN 1-24. https://doi.org/10.1007/978-1-4899-7460

Wall-scheffl, C.M., 2014. The balance between burden carrying, variable terrain, and thermoregulatory pressures in assessing morphological variation. Reconstructing Mobility: Environmental, Behavioral and Morphological Determinants, pp. 173-192. https://doi.org/10.1007/978-1-4899-7460-0.

Waltari, E., Hijmans, R.J., Peterson, A.T., Nyari, ' A.S., Perkins, S.L., Guralnick, R.P., 2007. XLocating pleistocene refugia: comparing phylogeographic and ecological niche model predictions. PloS One. https://doi.org/10.1371/journal.pone.0000563.

Wang, Y., 2017. Late pleistocene human migrations in China. Curr. Anthropol. 58 https://doi.org/10.1086/693899. S000-S000.

Wattanapituksakul, A., Filoux, A., Shoocongdej, R., Amphansri, A., Tumpeesuwan, S., 2018. Late pleistocene caprinae assemblages of Tham lod rockshelter (mae hong son province, northwest Thailand). Quat. Int. 493, 212-226. https://doi.org/10.1016/j. quaint.2018.06.003.

Whittey, E.M., 2017. Effects of Terrain on Reconstructions of Mobility in Past Populations. University of Massachusetts, Amherst.

Williams, A.N., Ulm, S., Goodwin, I.D., Smith, M., 2010. Hunter-gatherer response to late Holocene climatic variability in northern and central Australia. J. Quat. Sci. 25, 831-838. https://doi.org/10.1002/jqs.1416.

Zachwieja, A.J., 2019. Competition Index (CI) in Laos and Vietnam. University of Illinois at Urbana-Champaign. https://doi.org/10.13012/B2IDB-8284108 V1.

Zachwieja, A.J., 2020. Ecological Niche Models of Late Pleistocene Human Land Preference: an Australasian Test Case. University of Illinois at Urbana-Champaign https://doi.org/10.13012/B2IDB-0065911_V1.

Zachwieja, A.J., Shackelford, L.L., 2014. Post-Pleistocene gracilization and the effects of terrain on the lower limbs of modern humans. Am. J. Phys. Anthropol. 153 (S58), 280.

Zachwieja, A.J., Shackelford, L.L., 2018. Ecological niche models of human land use at the LastGlacial Maximum in Southeast Asia: a comparison of GARP and MaxEnt. PaleoAnthropology A1-A40.

Zachwieja, A., Shackelford, L., 2019. Sampling bias in the trend of postPleistoceneGracilization: how terrain affects lower limb robusticity. FASEB (Fed. Am. Soc. Exp. Biol.) J. 33 (S1), 612-619. 